\title{
Intracerebral Dendritic Cells Critically Modulate Encephalitogenic versus Regulatory Immune Responses in the CNS
}

\author{
Alla L. Zozulya, ${ }^{1,2}$ Sonja Ortler, ${ }^{1}$ JangEun Lee, ${ }^{2}$ Christian Weidenfeller, ${ }^{1}$ Matyas Sandor, ${ }^{2}$ Heinz Wiendl,,${ }^{1 \star}$ and \\ Zsuzsanna Fabry ${ }^{2 *}$ \\ ${ }^{1}$ Department of Neurology, University of Würzburg, 97080 Würzburg, Germany, and ${ }^{2}$ Department of Pathology and Laboratory Medicine, University of \\ Wisconsin-Madison, Madison, Wisconsin 53706
}

\begin{abstract}
Dendritic cells (DCs) appear in higher numbers within the CNS as a consequence of inflammation associated with autoimmune disorders, such as multiple sclerosis, but the contribution of these cells to the outcome of disease is not yet clear. Here, we show that stimulatory or tolerogenic functional states of intracerebral DCs regulate the systemic activation of neuroantigen-specific T cells, the recruitment of these cells into the CNS and the onset and progression of experimental autoimmune encephalomyelitis (EAE). Intracerebral microinjection of stimulatory DCs exacerbated the onset and clinical course of EAE, accompanied with an early T-cell infiltration and a decreased proportion of regulatory FoxP3-expressing cells in the brain. In contrast, the intracerebral microinjection of DCs modified by tumor necrosis factor $\alpha$ induced their tolerogenic functional state and delayed or prevented EAE onset. This triggered the generation of interleukin 10 (IL-10)-producing neuroantigen-specific lymphocytes in the periphery and restricted IL-17 production in the CNS. Our findings suggest that DCs are a rate-limiting factor for neuroinflammation.
\end{abstract}

Key words: neuroimmunology; dendritic cells; myelin oligodendrocyte glycoprotein antigen; intracerebral injection; T-cell immune responses; neuroinflammation; autoimmunity

\section{Introduction}

Since the first discovery of dendritic cells (DCs) in the CNS (Matyszak and Perry, 1996), these cells have emerged as pivotal players in the development and maintenance of CNS autoimmunity and inflammation (for review, see Becher et al., 2006; McMahon et al., 2006). DCs are rarely detected in the healthy CNS, and when they are present, they localize to vascular-rich tissues including the meninges and choroid plexus (Matyszak and Perry, 1996; Hanly and Petito, 1998; McMenamin, 1999; Serot et al., 2000; Greenwood et al., 2003). Several studies have demonstrated a substantial accumulation of DCs in the brain and spinal cord in response to local inflammation induced by autoimmunity, infection, or trauma (Hanly and Petito, 1998; McMenamin, 1999; Suter et al., 2003; McMahon et al., 2005; Newman et al., 2005; Bailey et al., 2007).

\footnotetext{
Received May 15, 2008; revised 0ct. 8, 2008; accepted Nov. 6, 2008.

This work was supported by National Institutes of Health Grant R01-NS 37570-01A2 (Z.F.), German Federal Ministry of Education and Research (BMBF, to H.W.), and German Research Foundation (SFB 581, TPA8, to H.W.). We thank Dr. Dana C. Baiu, Melissa G. Harris, and Heidi A. Schreiber for helpful discussions and critical review of this manuscript, and K. Macvilay and B. Reuter for technical assistance.

${ }^{*}$ H.W. and Z.F. contributed equally to this work.

Correspondence should be addressed to either of the following: Dr. Zsuzsanna Fabry, Department of Pathology and Laboratory Medicine, University of Wisconsin-Madison, 1300 University Avenue, 6130 MSCMadison, WI 53706, E-mail: zfabry@wisc.edu; or Dr. Heinz Wiendl, Department of Neurology, University of Würzburg, Josef-Schneider Strasse 11,97080 Würzburg, Germany, E-mail: heinz.wiend@@klinik.uni-wuerzburg.de.

A. L. Zozulya's present address: Department of Neurology, University of Würzburg, Josef-Schneider Strasse 11, 97080 Würzburg, Germany.

D0I:10.1523/JNEUROSCI.2199-08.2009

Copyright $\odot 2009$ Society for Neuroscience $\quad$ 0270-6474/09/290140-13\$15.00/0
}

The mechanism(s) by which DCs accumulate in the CNS under inflammatory conditions are not well understood.

The concordance of (1) accumulation of DCs in the CSF during progression of experimental autoimmune encephalomyelitis (EAE), the animal model of multiple sclerosis (MS) (Fischer and Bielinsky, 1999; Aloisi et al., 2000; Fischer et al., 2000; Fischer and Reichmann, 2001; Juedes and Ruddle, 2001; Kivisäkk et al., 2004), (2) the localization of DCs at the proximity of inflamed microvessels in MS lesions (Serafini et al., 2006), and (3) the production of astrocyte-derived chemokines that promote recruitment of DCs into the CNS (Ambrosini et al., 2005) strongly suggest that brain microvessel endothelial cells regulate the recruitment of DCs into the CNS. We have previously demonstrated that the transmigration of DCs across brain microvessel endothelium is regulated by macrophage inflammatory protein-1 $\alpha$ (MIP-1 $\alpha$ ), matrix metalloproteinases, and occludin perturbation. In addition, transmigration of DCs across brain microvessel endothelial cell monolayers contributed to the activation of antigen-specific T cells in vitro (Zozulya et al., 2007).

Conflicting data exist concerning the contribution of DCs to the outcome of CNS inflammation. It was proposed that DCs inhibit T-cell responses in the CNS (Suter et al., 2003), thus leading to protection from EAE (Kleindienst et al., 2005). However, other data suggests that DCs contribute to the induction and maintenance of neuroinflammation in EAE (Dittel et al., 1999; Weir et al., 2002). For example, increasing the number of DCs in the brain by systemic injection of FMS-like tyrosine kinase 3 
ligand (Flt-3L) leads to a substantial increase in the severity of clinical EAE symptoms (Greter et al., 2005). Conversely, inhibition of Flt-3L signaling ameliorates EAE, providing further evidence that DC numbers in the brain correlate with the outcome of autoimmune responses (Whartenby et al., 2005). In addition, CNS-resident $\mathrm{F} 4 / 80^{-} \mathrm{CD} 11 \mathrm{c}^{+} \mathrm{CD} 45^{\text {high }}$ cells isolated from brains of animals experiencing relapsing EAE or Theiler's murine encephalomyelitis virus-induced demyelinating disease can efficiently present endogenous myelin proteolipid protein (PLP) antigen and activate naive $\mathrm{PLP}_{139-151}$-specific T cells in vitro (McMahon et al., 2005). Further supporting a stimulatory role for DCs in regulating CNS immune responses, DCs were recently shown to be the only CNS antigen-presenting cells (APC) population capable of inducing memory cytotoxic T-cell responses in lymphocytic choriomeningitis virus infection (Lauterbach et al., 2006).

Taking advantage of methods used to generate stimulatory or inhibitory tolerogenic DCs that can be injected intracerebrally, we addressed the role of functionally different DCs on the generation of neuroantigen-specific T-cell responses and clinical outcome of EAE. Our data demonstrate that the quantity and functional phenotypes of DCs in the brain regulate the onset and progression of EAE.

\section{Materials and Methods}

Animals, immunizations, and EAE scoring. Four- to six-week-old female C57BL/6 mice were obtained from The Jackson Laboratory. 2D2 transgenic (Tg) mice were a gift from Dr. V. Kuchroo (Harvard Medical School, Boston, MA) (Bettelli et al., 2003). "Depletion of regulatory T-cell” (DEREG)-transgenic mice were a gift from Dr. T. Sparwasser (University of Muenchen, Munich, Germany) (Lahl et al., 2007). Experimental animals were housed in a pathogen-free facility at the University of Wisconsin, Medical School Animal Care Unit under guidelines of the National Institutes of Health or at the University of Wuerzburg Animal care facility according to German guidelines for animal care. Protocols for animal use were approved by the Animal Care and Use Committees of the University of Wisconsin-Madison and University of Wuerzburg (Regierung von Unterfranken).

For intracerebral injection, the mice were anesthetized by intraperitoneal injection of a ketamine $(90 \mathrm{mg} / \mathrm{kg})$-xylazine $(10 \mathrm{mg} / \mathrm{kg})$ mixture. Dendritic cells $\left(2.5 \times 10^{5}\right)$ loaded or unloaded with myelin oligodendrocyte glycoprotein peptide 35-55 ( MOG $\left._{35-55}\right)(10 \mu \mathrm{g} / \mathrm{ml}$ CyberSyn $)$ in 20 $\mu \mathrm{l}$ of PBS, or an equal volume of PBS was injected into the right frontal lobe with an insulin syringe attached to a penetrating depth controller as described previously (Ling et al., 2003, 2006). The injection was restricted to the ventral-posterior region of the frontal lobe, and the penetrating depth of the syringe was $1.55 \mathrm{~mm}$ from the surface of the brain. For each intracerebral injection, the solution was injected slowly, and then the syringe was held in place for an additional minute to reduce backfilling of injected solution.

In some experiments, $5 \times 10^{6} 2 \mathrm{D} 2$ transgenic T cells were adoptively transferred into mice (Sewell et al., 2003). Where indicated, DCs were incubated in the presence of $200 \mathrm{ng} / \mathrm{ml}$ pertussis toxin (PTX) (List Biological Laboratories) during antigen pulsing (Marriott et al., 1999). PTXtreated DCs were extensively washed before injection. No significant effect of PTX on DC phenotype, maturation and function was observed in vitro (Karman et al., 2004a) (data not shown).

For EAE induction, emulsion of equal volumes of complete Freund's adjuvant (CFA) $(5 \mathrm{mg} / \mathrm{ml})$ and $200 \mu \mathrm{g} \mathrm{MOG}_{35-55}$ supplemented with Mycobacterium tuberculosis (Strain H37Ra; Difco) were injected subcutaneously in the scapular region of each mouse. PTX ( $400 \mathrm{ng} /$ mouse) was intraperitoneally injected on the days 0 and 2 relative to immunization. Clinical scores were monitored daily in a blind manner and recorded as follows: 0 , no clinical disease; 1 , flaccid tail; 2 , gait disturbance or hind limb weakness; 3 , hind limb paralysis and no weight bearing on hind limbs; 4 , hind limb and forelimb paralysis and reduced ability to move around the cage; and 5, moribund or dead. The mean daily clinical score and SEM were calculated for each group. The significance of differences was calculated by Student's $t$ and Wilcox tests as described by Fleming et al. (2005).

Generation of different types of DCs. DCs were generated as described previously (Inaba et al., 1992; Karman et al., 2004a). Briefly, bone marrow obtained from femurs and tibias of C57BL/6 mice was washed and plated in 24-well plates in RPMI 1640 with 10\% FBS supplemented with $100 \mathrm{U} / \mathrm{ml}$ penicillin/streptomycin and $20 \mathrm{ng} / \mathrm{ml}$ granulocyte macrophage colony-stimulating factor (GM-CSF). GM-CSF was titrated from supernatants of the GM-CSF-secreting X63 cell line (a gift from Dr. A. Erdei, Eotvos University, Budapest, Hungary). Seven days after GM-CSF cultures, the nonadherent and loosely adherent cells were removed and replated in the absence of GM-CSF and cultured together for $4 \mathrm{~h}$ with or without $\mathrm{MOG}_{35-55}$ peptide $(10 \mu \mathrm{g} / \mathrm{ml})$. Nonadherent cells were collected for use as described previously (Karman et al., 2004a). To generate semimatured or fully matured DCs, cells were treated for $4 \mathrm{~h}$ with tumor necrosis factor (TNF)- $\alpha$ (500 U/ml; PeproTech) or lipopolysaccharide (LPS) $(10 \mu \mathrm{g} / \mathrm{ml})$, with or without $\mathrm{MOG}_{35-55}$ as described by Menges et al. (2002).

Isolation of spleen, lymph nodes, and CNS cells. Spleen and lymph nodes were dissected, weighed, and transferred into cold HBSS (Cellgro). The isolated lymphocytes were washed with cold HBSS and resuspended either in staining buffer (PBS containing $1 \%$ BSA and $0.1 \% \mathrm{NaN}_{3}$ ) for a direct cell-surface staining, or in culture medium (RPMI supplemented with $10 \%$ FBS) for an overnight cell culture followed by intracellular cytokine staining. For spleens, red blood cells were lysed with Tris$\mathrm{NH}_{4} \mathrm{Cl}$. Minced brain tissue was processed with Medicon inserts (BD Biosciences). Brain lymphocytes were isolated from the interface of a Percoll density gradient as described previously (Sewell et al., 2004). For some samples, the total number of isolated cells per gram of tissue was calculated.

Flow cytometry. Single-cell suspensions were stained with saturating concentrations of antibodies at $4^{\circ} \mathrm{C}$ for $30 \mathrm{~min}$. Monoclonal antibodies used for cell surface staining were purchased from BD Biosciences and included anti-CD8, anti-CD4, anti-v $\beta 11$, anti-LFA-1, anti-CD45, anti$\mathrm{CD} 11 \mathrm{~b}$, and anti-FoxP3. Nonspecific binding to cell surface Fc receptors was blocked with unlabeled Fc $\gamma$ RII/Fc $\gamma$ RIII-specific antibody (clone 2.4G2) as described previously (Karman et al., 2004a). For intracellular staining of interferon (IFN)- $\gamma$, single-cell suspensions from spleen $\left(10^{6}\right.$ cells $/ \mathrm{ml})$ or brain lymphocyte preparation $\left(10^{5} \mathrm{cells} / \mathrm{ml}\right)$ were cultured for $12 \mathrm{~h}$ in 96-well plates in RPMI-10\% FBS with or without $\mathrm{MOG}_{35-55}$ $(10 \mu \mathrm{g} / \mathrm{ml})$ in the presence of GolgiStop $(1 \mu \mathrm{l} / \mathrm{ml})$ (BD Biosciences) before being stained for extracellular ligands and intracellular cytokines. In some experiments, the supernatants of restimulated cells were assessed by cytokine bead array for measurement of IFN- $\gamma$, interleukin 17 (IL-17), and IL-10 according to the manufacturer's instruction (Bender MedSystems). Stained cells were acquired on a four-color FACSCalibur cytometer and were analyzed with FlowJo software (TreeStar) version 7.2.1.

Carboxyfluorescein succinimidyl ester staining. Single-cell suspensions from the spleen of a 2D2 mouse were incubated with carboxyfluorescein succinimidyl ester (CFSE) (2.5 $\mu \mathrm{M}$; Invitrogen) in HBSS for $5 \mathrm{~min}$ at $37^{\circ} \mathrm{C}$. The reaction was quenched with $20 \% \mathrm{FBS}$. Cells were processed for adoptive transfer into C57BL/6 mice $\left(5 \times 10^{6}\right.$ cells in $100 \mu$ of PBS per mouse).

Statistical analysis. Differences between groups were determined with unpaired Mann-Whitney and Wilcox tests. $p$ values $<0.05$ were considered to be significant.

\section{Results}

Neuroantigen-specific encephalitogenic T cells invade the CNS in response to intracerebral, but not systemic, injections of stimulatory dendritic cells

The accumulation of activated neuroantigen-specific $\mathrm{T}$ cells in the nervous tissue is a hallmark of autoimmune diseases of the CNS. Although the brain parenchyma is usually devoid of DCs, several recent studies have demonstrated that these cells are prominent components of CNS infiltrates in EAE and MS 
A
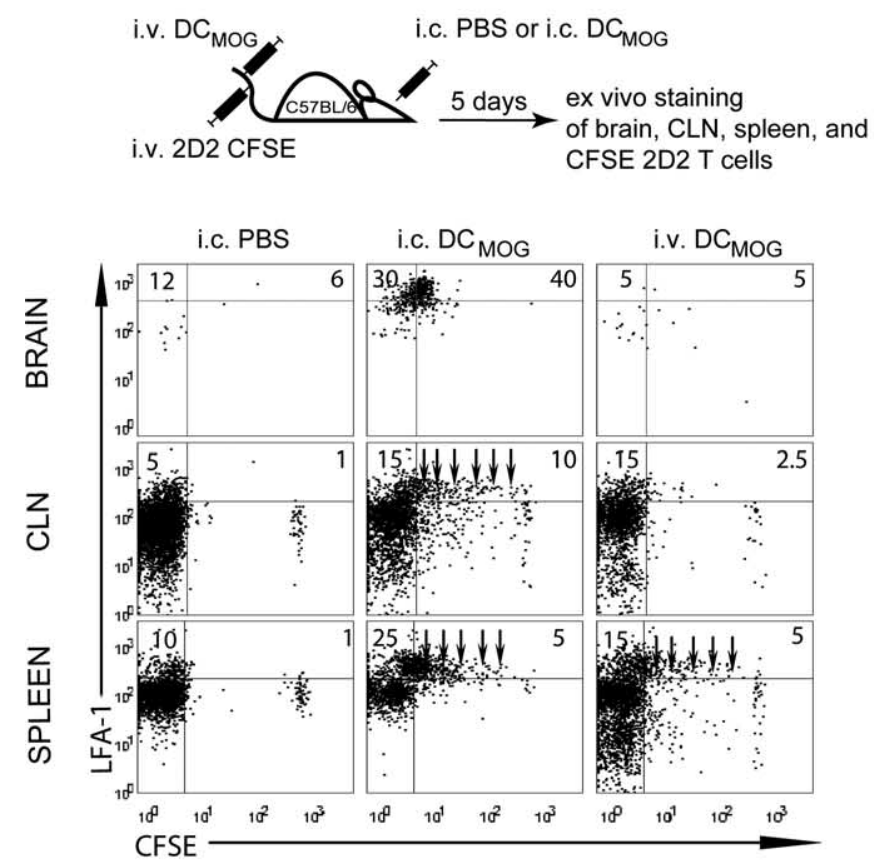

B

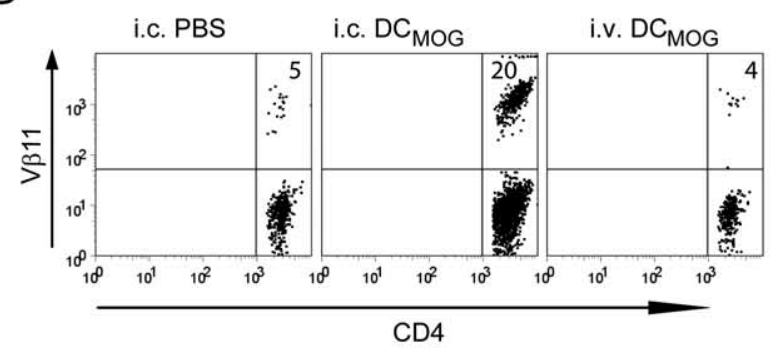

C

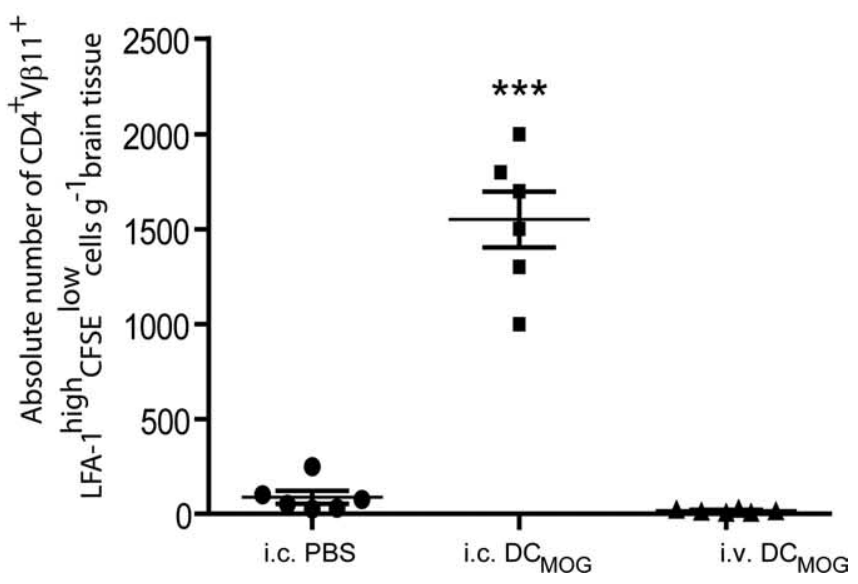

Figure 1. Intracerebral but not systemic $D C_{\text {MOG }}$ injection results in MOG-specific $2 D 2$ T-cell expansion in the periphery and the accumulation of these cells in the brain. $A$, Intracerebral PBS, intracerebral $\mathrm{DC}_{\mathrm{MOG}}$, or intracerebral $\mathrm{DC} \mathrm{C}_{\mathrm{MOG}}$ injections were followed by an adoptive transfer of $5 \times 10^{6} \mathrm{CFSE}$-labeled $2 \mathrm{D} 2 \mathrm{Tg} \mathrm{T}$ cells into $\mathrm{C57BL} / 6$ mice to track the migration of V $\beta 11^{+} \mathrm{CD} 4{ }^{+} \mathrm{T}$ cells. The dot plots represent LFA- 1 expression and CFSE proliferation of adoptively transferred CD4 ${ }^{+} \mathrm{V} \beta 11^{+}$lymphocytes in the brain, CLN, and spleen of C57BL/6 mice. Arrows indicate cycles of cell proliferation. B, Flow cytometry dot plots of the accumulated $C D 4^{+} \mathrm{V} \beta 11^{+}$cells in the brain. Numbers in quadrants indicate percent positive cells. $C$, Absolute number of CD4 ${ }^{+} \mathrm{V} \beta 11^{+} \mathrm{LFA}-$ $1^{\text {high }}{ }^{2}$ SSE ${ }^{\text {low }}$ T cells in brain tissue. A total of six mice were analyzed in each experimental group. Each symbol represents a single mouse; small horizontal bars indicate the mean. ${ }^{* * *} p<0.0001$ (ANOVA).

(Fischer and Reichmann, 2001; Suter et al., 2003; Greter et al., 2005; Bailey et al., 2007; Deshpande et al., 2007). To determine whether increasing the number of stimulatory DCs in the brain induces antigen-specific immune responses in the periphery, we injected $\mathrm{MOG}_{35-55}$ peptide-presenting DCs intracerebrally (intracerebral $\mathrm{DC}_{\mathrm{MOG}}$ ) into $\mathrm{C} 57 \mathrm{BL} / 6$ mice and subsequently analyzed the proliferation of MOG-specific (2D2) T cells in different organs $5 \mathrm{~d}$ after their adoptive transfer. We have previously shown that intracerebral microinjection of either ovalbumin (OVA) (Ling et al., 2006) or OVA-loaded DCs (Karman et al., 2004a) initiated antigen-specific T-cell responses in the cervical lymph nodes (CLN), spleen and the homing of OVA-specific T cells into the brain (Karman et al., 2004a). To extend these studies, we addressed whether the spatial localization of DCs in the brain is important for inducing neuroantigen-specific T-cell responses in the brain and CLNs. CFSE-labeled CD $4^{+} \mathrm{T}$ cells from 2D2 mice, expressing a Tg T-cell receptor specific for $\mathrm{MOG}_{35-55}$ peptide and defined by $\mathrm{V} \alpha 3.2$ and $\mathrm{V} \beta 11^{+}$subunit chains (Bettelli et al., 2003), were adoptively transferred into three groups of C57BL/6 animals (Fig. 1A, top). These groups included intracerebrally injected $\mathrm{PBS}$ and $\mathrm{DC}_{\mathrm{MOG}}$ mice and intravenously injected $\mathrm{DC}_{\mathrm{MOG}}$ mice (Fig. $1 \mathrm{~A}$, left, middle, and right of bottom panel, respectively). Five days after immunization, we analyzed the accumulation and activation of CFSE-labeled 2D2 Tg CD4 ${ }^{+}$ $\mathrm{T}$ cells in the brain, CLNs and spleen. Our data show that intracerebral but not systemic injection of DCs resulted in antigenspecific T-cell accumulation in the brain. Based on high expression of LFA-1, antigen-specific CFSE-labeled T cells in the brain were highly activated (Fig. $1 A$, top center of bottom panel). As expected, MOG-specific T cells were stimulated in the CLN and spleen, where they underwent several cycles of proliferation before their accumulation in the brain (Fig. $1 \mathrm{~A}$, bottom of bottom panel, arrows). Only intracerebral injection of $\mathrm{DC}_{\mathrm{MOG}}$ induced the proliferation of MOG-specific T cells in the CLN and spleen and the accumulation of neuroantigen-specific $\mathrm{T}$ cells in the CNS. In contrast, intravenous injection of $\mathrm{DC}_{\mathrm{MOG}}$ resulted in 2D2 T-cell proliferation in the spleen but not in the CLN, and no accumulation of cells was found in the brain (Fig. $1 \mathrm{~A}$, most right column of bottom panel). As a control for injection-induced microtrauma, we injected the same volume of sterile PBS intracerebrally. Importantly, PBS injection alone did not induce proliferation of antigen-specific $\mathrm{T}$ cells in the periphery or the accumulation of these cells in the brain (Fig. $1 \mathrm{~A}$, far left plots). No MOG-specific T-cell accumulation in the CNS was observed after intracerebral injection of DCs pulsed with ovalbumin (intracerebral $\mathrm{DC}_{\mathrm{OVA}}$ ) or other MHCII (major histocompatibility complex II)-restricted peptides (e.g., pigeon cytochrome $c$, PCC) (data not shown). Because we previously demonstrated that only the relevant antigen-expressing DCs induce antigen-specific T-cell accumulation in the CNS (Karman et al., 2004a, 2006), irrelevant peptides, such as OVA-expressing DCs, were not included in further studies. Analysis of the absolute number of tissue infiltrating $\mathrm{CD} 4{ }^{+} \mathrm{V} \beta 11^{+} \mathrm{LFA}-1^{\text {high }} \mathrm{CFSE}^{\text {low }}$ cells further confirmed that activated antigen-specific $\mathrm{CD} 4{ }^{+} \mathrm{T}$ cells were accumulating in the brain when intracerebrally injected antigen-presenting DCs were present (Fig. 1B,C). 


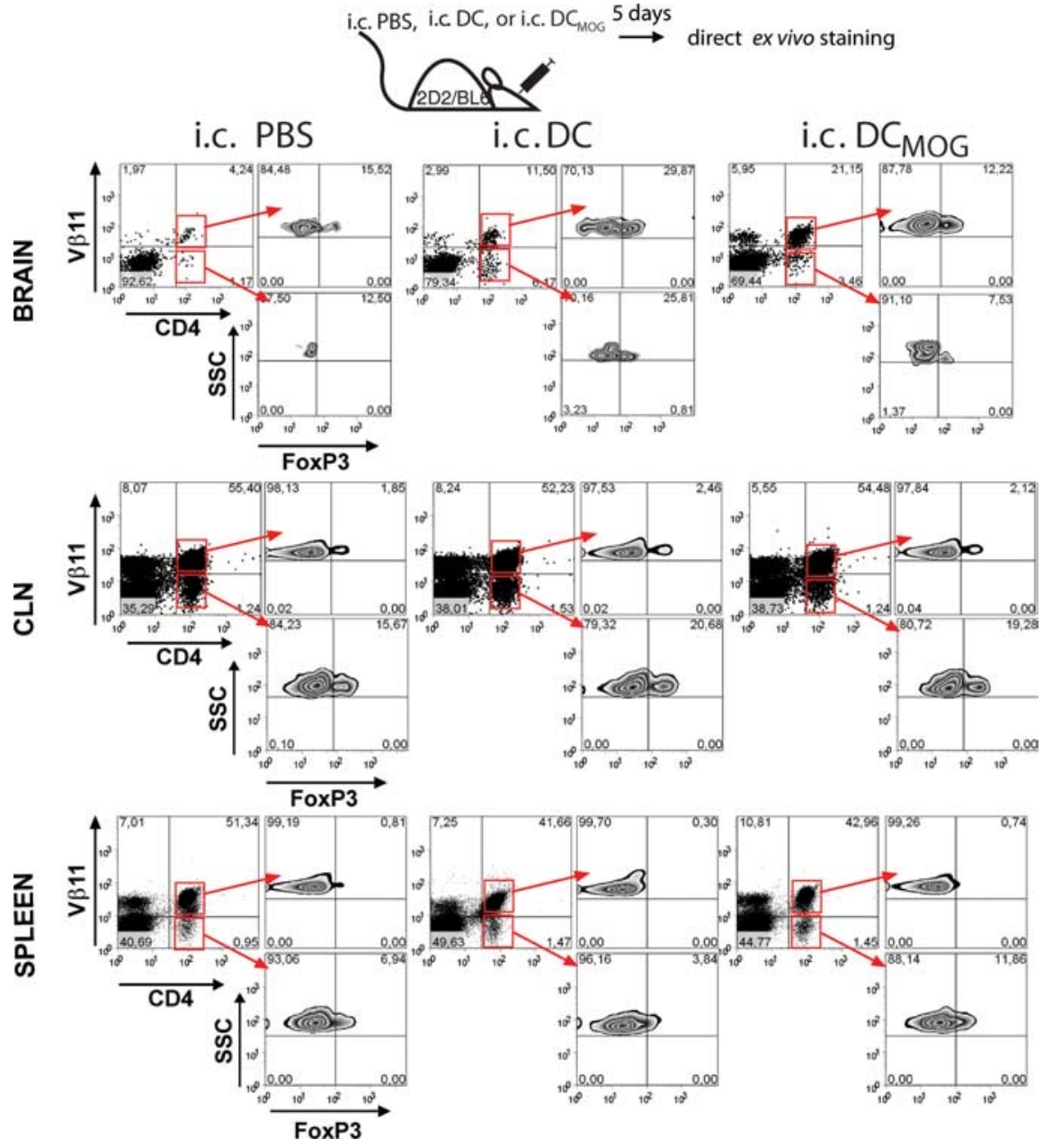

Figure 2. Intracerebral injection of $\mathrm{DC}_{\mathrm{MOG}}$ induces $\mathrm{V} \beta 11^{+} \mathrm{CD} 4{ }^{+} \mathrm{MOG}$-specific T-cell accumulation in the brain with the prevalence of MOG over non-MOG-specific $\mathrm{V} \beta 11^{+}{ }^{+}$FoxP3 ${ }^{+} \mathrm{T}_{\text {reg }}$ cells. 2D2/Bl6 mice were intracerebrally injected with PBS, unpulsed $D C S$, or DCs loaded with MOG (DC ${ }_{M O G}$ ). Five days after immunization, CNS, CLN, and spleen cells were analyzed by flow cytometry. Plots are gated for $C D 4^{+} \mathrm{V} \beta 11^{+}$(MOG-specific) and CD4 ${ }^{+} \mathrm{V} \beta 11^{-}$(non-MOG-specific) T cells (left) and analyzed for FoxP3 expression (right). Numbers in quadrants indicate the percentage of cells in each gate. Data plotted as dot plots of $\mathrm{CD}^{+} \mathrm{V} \beta 11^{+}, \mathrm{CD} 4^{+} \mathrm{V} \beta 11^{-}$and as contour plots of FoxP3 distribution in different organs in response to intracerebral injections. Data are from two experiments with three mice per group.

It was shown previously that MOG-specific FoxP3 ${ }^{+}$regulatory $\mathrm{T}\left(\mathrm{T}_{\text {reg }}\right)$ cells accumulate in the CNS during EAE (Korn et al., 2007; O'Connor et al., 2007). To determine whether intracerebral DCs could also induce the accumulation of antigen-specific $\mathrm{T}_{\text {reg }}$ cells in the brain, we intracerebrally injected 2D2 Tg mice with MOG-pulsed DCs and tracked the appearance of both MOGspecific and nonspecific $\mathrm{T}_{\text {reg }}$ cells in the CNS and peripheral tissues (Fig. 2, top). We also confirmed our previous results showing that intracerebral $\mathrm{DC}_{\mathrm{MOG}}$ injection induces $\mathrm{V} \beta 11^{+} \mathrm{CD} 4^{+}$ MOG-specific T-cell accumulation in the brain (Fig. 2, top right panel of bottom panel). Intracerebral $\mathrm{DC}_{\mathrm{MOG}}$ injection resulted in approximately five times higher infiltration of MOG-specific $\mathrm{V} \beta 11^{+} \mathrm{CD}^{+} \mathrm{T}$ cells in the brain compared with the intracerebral PBS injections (Fig. 2, top left). Unpulsed DCs were used as a control to test whether the observed effects depended on the accessibility of MOG antigen to DCs. Interestingly, we detected two times higher infiltration of MOG-specific $\mathrm{V} \beta 11^{+} \mathrm{CD} 4{ }^{+} \mathrm{T}$ cells in the brain after the injection of unpulsed DCs compared with intracerebral PBS injections, but this was clearly less compared with intracerebral $\mathrm{DC}_{\mathrm{MOG}}$ injection (Fig. 2, top center). This may indicate that DCs can uptake neuroantigens in the brain and induce the accumulation of antigenspecific T cells in the CNS. Regardless of the antigen, intracerebral DCs induced the presence of FoxP3-expressing $\mathrm{CD}_{4}{ }^{+} \mathrm{T}$ cells with the prevalence of MOG-specific $\mathrm{V} \beta 11^{+}$FoxP3 $^{+} \mathrm{T}_{\text {reg }}$ cells. Although $\sim 2 \%$ of MOG-specific $\mathrm{T}_{\text {reg }}$ cells were found in the CLN in all groups of animals (Fig. 2, middle), no MOG-specific $\mathrm{T}_{\text {reg }}$ cells were detected in the spleen after intracerebral injections (Fig. 2, bottom). These experiments demonstrate that intracerebral DCs elicit the accumulation of both encephalitogenic and regulatory $\mathrm{T}$ cells in the CNS. Altogether, these data suggest that antigen-carrying DCs in the brain contribute to the neuroantigenspecific T-cell accumulation in the CNS.

When we used transgenic mice termed DEREG mice (Lahl et al., 2007), in which FoxP $3^{+}$cells can easily be detected and followed for tissue distribution based on GFP expression regardless of their antigen specificity, we did not observe any differences in the fraction of $\mathrm{GFP}^{+} \mathrm{CD} 4{ }^{+}$FoxP3expressing $\mathrm{T}_{\text {reg }}$ cells in response to different types of DCs or PBS injections in the periphery (supplemental Fig. 1, available at www. jneurosci.org as supplemental material). However, higher percentages of CNSderived $\mathrm{GFP}^{+}$cells were detectable in intracerebrally injected animals with no differences between intracerebrally injected PBS and $\mathrm{DC}_{\mathrm{MOG}}$ groups compared with intravenous $\mathrm{DC}_{\mathrm{MOG}}$. This suggests that microtrauma induced by intracerebral injection of PBS or DCs was not sufficient to induce the accumulation of antigen-specific $\mathrm{T}$ cells in the brain but attracts $T_{\text {reg }}$ cells that can be found in the brain $5 \mathrm{~d}$ after injection (supplemental Fig. 1, available at www.jneurosci.org as supplemental material).

Clinical and immunological signs of EAE are exacerbated in response to intracerebral $\mathrm{DC}_{\mathrm{MOG}}$ at different phases of $\mathrm{EAE}$ In Figure 1, we demonstrated that intracerebrally injected DCs that carry MOG antigen contribute to the activation of MOGspecific $\mathrm{T}$ cells in the periphery and the accumulation of these cells in the CNS. From our previous studies, we also learned that in addition to presenting antigen in the CNS, DCs can deliver antigens from inflamed CNS and induce homing of peripheral antigen-specific T cells into nervous tissue (Karman et al., 2004b; Ling et al., 2006). To further understand the in vivo significance of these results, we extended our work to analyze whether intracerebrally injected DCs loaded with MOG peptide would influence the clinical course or onset of EAE. In these experiments, we also used DCs that were pulsed with MHC class II-specific OVA peptide $\left(\mathrm{DC}_{\mathrm{OVA}}\right)$ in parallel with $\mathrm{DC}_{\mathrm{MOG}}$. Thus, $\mathrm{DC}_{\mathrm{MOG}}, \mathrm{DC}_{\mathrm{OVA}}$, or equal volume of sterile PBS was intracerebrally injected into the CNS, and $5 \mathrm{~d}$ later, EAE was actively induced by immunization with $\mathrm{MOG}_{35-55}$ antigen (Fig. 3A, top). Mice intracerebrally injected with $\mathrm{DC}_{\mathrm{MOG}}$ experienced a significantly accelerated EAE onset and a more progressive course of the disease compared with 


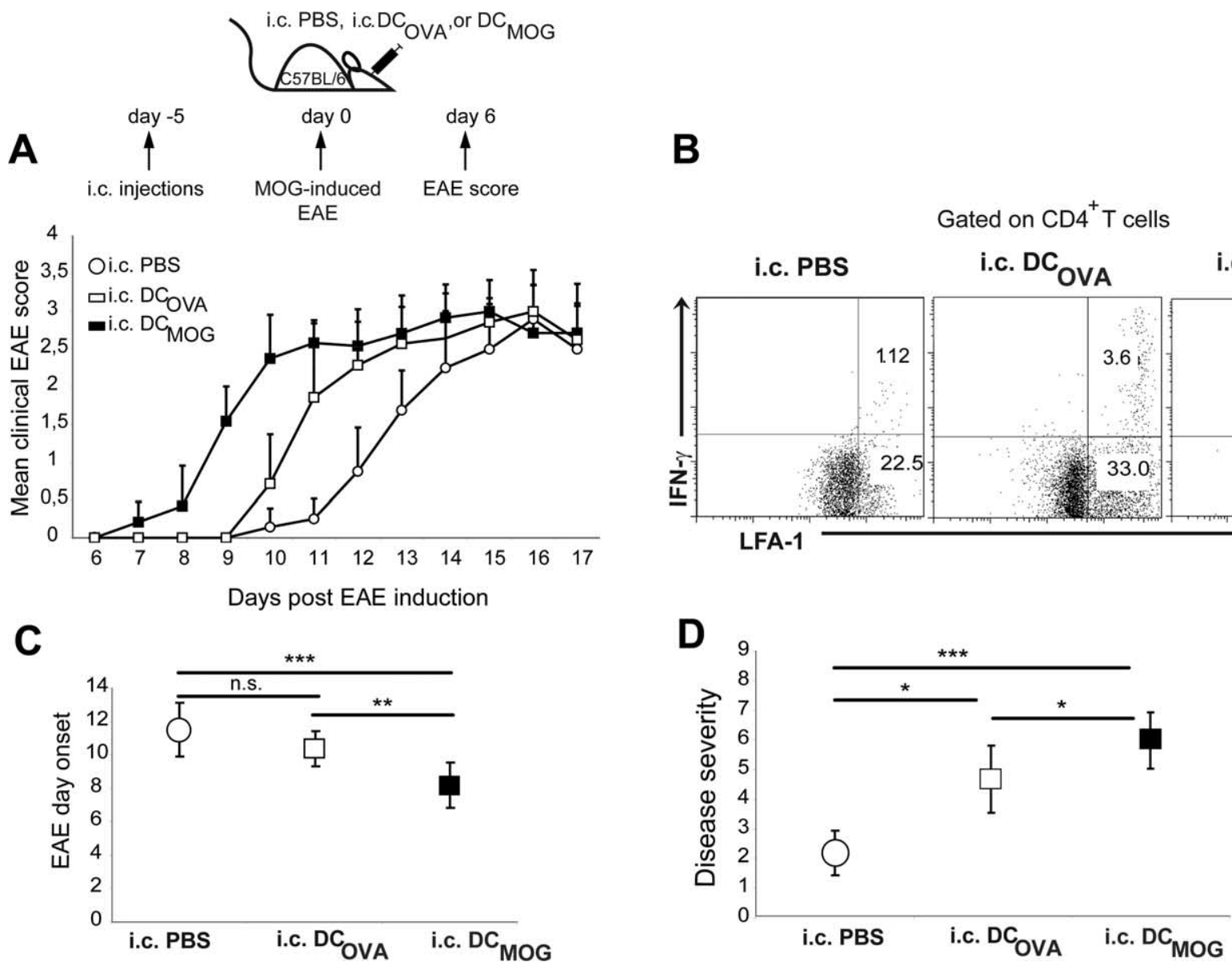

Figure 3. Intracerebral $D C_{M O G}$ injection induces an earlier onset of EAE, altering the severity and duration of the disease. Mice intracerebrally injected with $P B S, D C_{O V A}$, or $D C_{M O G}$ were induced with MOG-EAE $5 \mathrm{~d}$ after injections and followed for EAE clinical scores. $\boldsymbol{A}$, Daily mean clinical EAE score for each group of mice is plotted. $\boldsymbol{B}$, Intracellular IFN- $\gamma$ staining on CNS-purified and MOG $35-55$ peptide restimulated leukocytes. Dot plots are gated on $\mathrm{CD} 4{ }^{+} \mathrm{T}$ cells, and numbers demonstrate the percentage of IFN- $\gamma$-positive cells on LFA- $1^{+}$activated cells. Data acquired from brain tissue $7 \mathrm{~d}$ after EAE induction. $C$, Graphical representation of EAE day onset for intracerebral $D C_{\text {MOG }}$-immunized animals compared with intracerebrally injected PBS and $D C_{\text {OVA }}$ mice. (Student's $t$ test, ${ }^{* * *} p=0.0003$ for intracerebrally injected PBS group compared with intracerebrally injected $D C_{\text {MOG }}$ group; ${ }^{* *} p=0.005$ for intracerebral $D C_{\text {OvA }}$ compared with intracerebral $D C_{\text {MOG }}$.) $D$, Graphical representation of the disease severity that summarizes the number of days with $E A E$ clinical scores $\geq 2.5$ for intracerebral $D C_{M O G}{\text { compared with intracerebrally injected } P B S \text { and } D C_{O V A}}$ mice. (Student's $t$ test, ${ }^{* * *} p=0.0005$ for intracerebral PBS compared with intracerebral $D C_{M O G} ;{ }^{*} p=0.01$ for intracerebral PBS compared with intracerebral $D C_{O V A}$ and intracerebral $D C_{O V A}$ compared with intracerebral $D C_{\text {MOG }}$.)

\section{Table 1. EAE induction after intracerebral immunizations}

\begin{tabular}{|c|c|c|c|c|}
\hline Immunization & $\begin{array}{l}\text { Incidence } \\
(\%)\end{array}$ & $\begin{array}{l}\text { No. } \\
\text { of mice }\end{array}$ & $\begin{array}{l}\text { Mean } \\
\text { day onset }^{a}\end{array}$ & $\begin{array}{l}\text { Mean } \\
\text { maximal score }\end{array}$ \\
\hline Intracerebral PBS + subcutaneous CFA-MOG & 100 & 8 of 8 & $11.5 \pm 1.2$ & $2.26 \pm 0.3$ \\
\hline Intracerebral $\mathrm{DC}_{\mathrm{MOG}}+$ subcutaneous CFA-MOG & 100 & 12 of 12 & $8.2 \pm 1.0^{* * * c}$ & $2.62 \pm 0.35^{* c}$ \\
\hline Intracerebral DC $\mathrm{OVA}_{\mathrm{O} A}+$ subcutaneous CFA-MOG & 100 & 9 of 9 & $10.4 \pm 0.5^{* * d}$ & $2.6 \pm 0.25^{* e}$ \\
\hline Intracerebral $\mathrm{DC}_{\mathrm{MOG}}+$ subcutaneous CFA & 0 & 0 of 6 & & \\
\hline
\end{tabular}

${ }^{a}$ Mean day of onset was calculated for the mice which developed EAE. Data represent mean $\pm \mathrm{SE}$.

${ }^{b}$ Mean maximal score was calculated for all mice in the group. Data represent mean $\pm \mathrm{SE}$.

${ }^{c} p$ values of intracerebral $D C_{M O G}$ compared with intracerebral PBS group.

${ }^{d} p$ values of intracerebral $D C_{O V A}$ compared with intracerebral $D C_{\text {MOG }}$.

${ }^{e} p$ values of intracerebral $D C_{O V A}$ compared with intracerebral $P B S$ group.

${ }^{*} p<0.05,{ }^{* *} p<0.01,{ }^{* * *} p<0.001$; Student's $t$ test.

intracerebrally injected PBS and $\mathrm{DC}_{\mathrm{OVA}}$ animals (Fig. $3 A$, bottom; Table 1). Accordingly, the frequency of $\mathrm{CD} 4{ }^{+} \mathrm{LFA}-1^{+}$doublepositive IFN- $\gamma$-producing cells in the brain of intracerebrally injected $\mathrm{DC}_{\mathrm{OVA}}$ mice $(3.6 \%)$ was significantly lower at $7 \mathrm{~d}$ after EAE induction compared with intracerebrally injected $\mathrm{DC}_{\mathrm{MOG}}(16.7 \%)$ mice (Fig. $3 B$ ). Also, a higher percentage of activated LFA- ${ }^{+} \mathrm{CD} 4{ }^{+}$ $\mathrm{T}$ cells was observed in intracerebrally injected $\mathrm{DC}_{\mathrm{MOG}}$ mice $(\sim 80 \%)$ compared with intracerebrally injected $\mathrm{DC}_{\mathrm{OVA}}(37 \%)$ and PBS $(23.5 \%)$ mice. Still, modest acceleration of EAE clinical scores
(Fig. 3A) and cellular infiltration (Fig. 3B) was observed in response to intracerebrally $\mathrm{DC}_{\mathrm{OVA}}$ injections. This might suggest that OVApulsed and intracerebrally injected DCs could amplify neuroinflammation by contributing to CNS antigen-specific T-cell activation. In support of this, myeloid DCs were recently described as a superior CNS cell population in EAE mice, capable of inducing naive CD4 ${ }^{+}$ T-cell proliferation and cytokine production with endogenous peptides (Bailey et al., 2007) (for review, see Miller et al., 2007b).

To test whether the induction of neuroantigen-specific $\mathrm{T}$ cells 

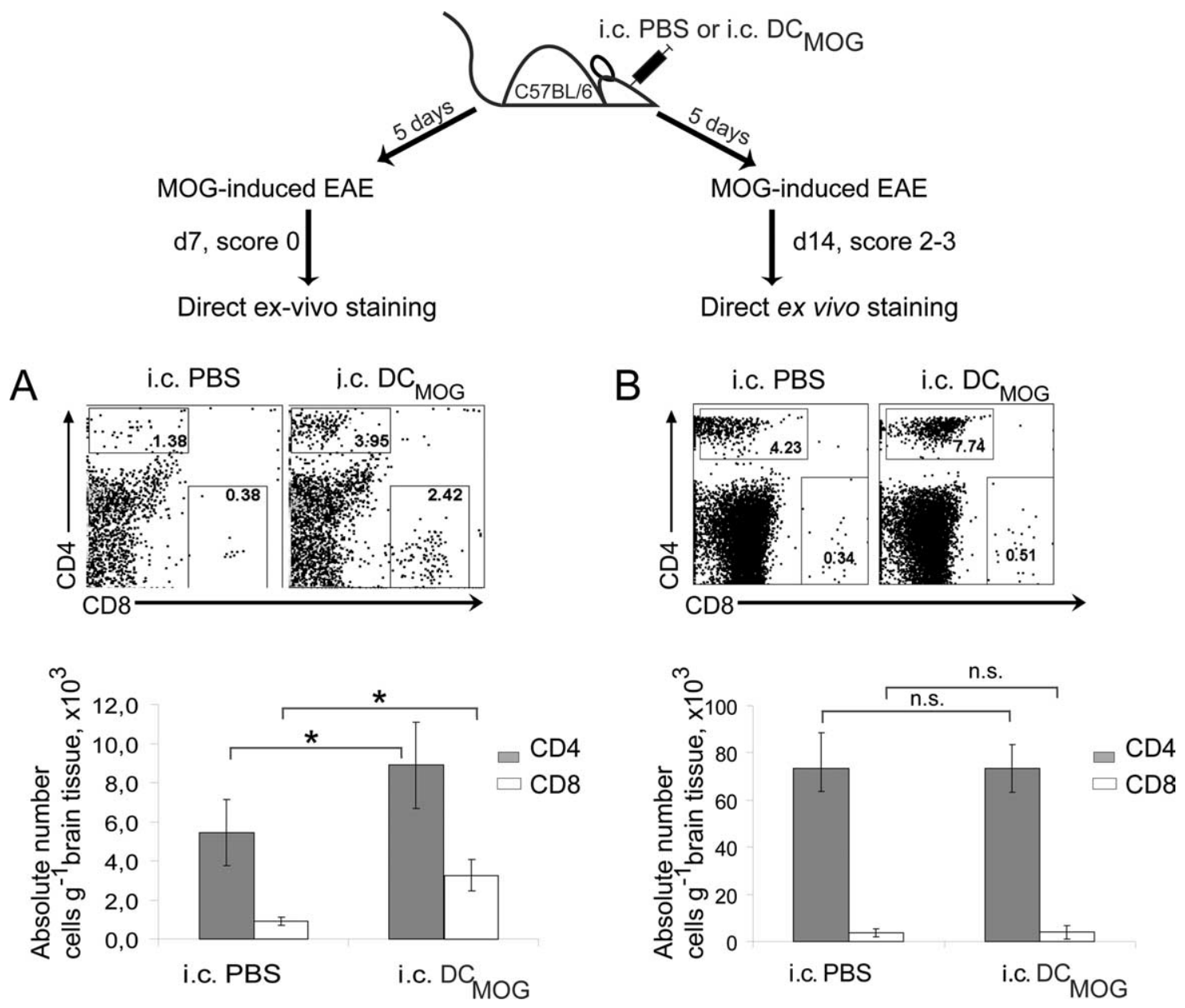

Figure 4. Intracerebral $D C_{M O G}$ injection results in increased infiltration of $\mathrm{T}$ cells into the $\mathrm{CNS}$ before EAE onset. Intracerebral $\mathrm{DC}_{\mathrm{MOG}}$ or intracerebrally injected PBS mice were induced with $E A E 5 \mathrm{~d}$ after injection and used for T-cell analysis before EAE onset (day 7 after EAE induction) and at the peak of the disease (day 14 after EAE induction). $A, B$, The dot plots represent the percentage of CD4 ${ }^{+}$and CD8 ${ }^{+}$ CNS infiltrating T cells (top) and absolute cell number per gram of CNS tissue (bottom) $7 \mathrm{~d}(\boldsymbol{A})$ and $14 \mathrm{~d}(\boldsymbol{B})$ after EAE immunization. Dot plots presented are representative analyses of unpooled samples from five separate experiments, each with three to four mice per group. [Two-tailed Student's t test, $p=0.01$ for CD4 ${ }^{+}$T cells (gray bars) and $p=0.05$ for CD8 ${ }^{+}$T cells (white bars).]

by intracerebral $\mathrm{DC}_{\mathrm{MOG}}$ in conjunction with $\mathrm{CFA}$ is sufficient to induce clinical EAE, one group of intracerebrally injected animals (intracerebral $\mathrm{DC}_{\mathrm{MOG}}$ ) received only subcutaneous CFA and no MOG antigen during EAE induction (Table 1). These mice did not develop clinical signs of EAE, indicating that subcutaneously injected MOG antigen is still required for full susceptibility to clinical disease (Table 1).

Graphical representation of EAE day onset for intracerebrally $\mathrm{DC}_{\mathrm{MOG}}$-immunized animals compared with intracerebrally injected $\mathrm{DC}_{\mathrm{OVA}}$ and PBS mice confirms an earlier onset of disease (Fig. 3C). Likewise, graphical representation of the disease severity in number of days with EAE clinical scores $\geq 2.5$ from all animals involved in EAE experiments (Table 1) shows a higher number of mice with EAE score of 2.5 or above in intracerebrally injected $\mathrm{DC}_{\mathrm{MOG}}$ groups compared with intracerebrally injected PBS and $\mathrm{DC}_{\mathrm{OVA}}$ groups (Fig. 3D). A significantly increased disease severity was also observed between intracerebrally injected PBS and $\mathrm{DC}_{\mathrm{OVA}}$ animals, proving DC contribution to CNStriggered neuroinflammation (Fig. 3D). Immunohistopathology was performed in addition to clinical EAE scoring, and cellular infiltration was analyzed in the animal cohorts described above. On day 17 after EAE induction, immunohistopathology directly correlated with the EAE development in all experimental groups and was followed by a higher cellular infiltration and demyelina- tion degree at lesion sites in the optic nerves (supplemental Fig. 2, available at www.jneurosci.org as supplemental material), brain and spinal cord tissues (not shown) in intracerebrally injected $\mathrm{DC}_{\mathrm{MOG}}$ and $\mathrm{DC}_{\mathrm{OVA}}$ animals compared with intracerebrally injected PBS animals. These data show that injected DCs contribute to cellular infiltration and demyelination in the CNS.

The intracerebral $\mathrm{DC}_{\mathrm{OVA}}$ group in the last set of experiments has helped us conclude that antigen-specific T cells do not accumulate in the CNS in the absence of their specific antigen and neuroinflammation, and that intracerebral injections of PBS or DCs (pulsed or not pulsed with antigen) induces the same level of microtrauma in the brain that does not result in the accumulation of antigen-specific cells in this tissue.

We next wanted to determine whether the accumulation of $\mathrm{T}$ cells in the brain after intracerebral $\mathrm{DC}_{\mathrm{MOG}}$ injection and $\mathrm{EAE}$ induction correlates with clinical disease (Fig. 4, experimental scheme). Our data show that intracerebral $\mathrm{DC}_{\mathrm{MOG}}$ injection resulted in earlier accumulation of $\mathrm{CD}^{+}{ }^{+}$and also CD8 ${ }^{+} \mathrm{T}$ cells in the brain (preclinical phase) (Fig. $4 A$ ). At day 14 after EAE induction (peak of disease), differences in T-cell accumulation between intracerebral PBS and intracerebral $\mathrm{DC}_{\mathrm{MOG}}$ were not statistically significant (Fig. $4 \mathrm{~B}$ ). These data indicate that increasing the number of MOG-presenting DCs in the CNS induces early immune responses in the periphery, and the accelerated accumu- 


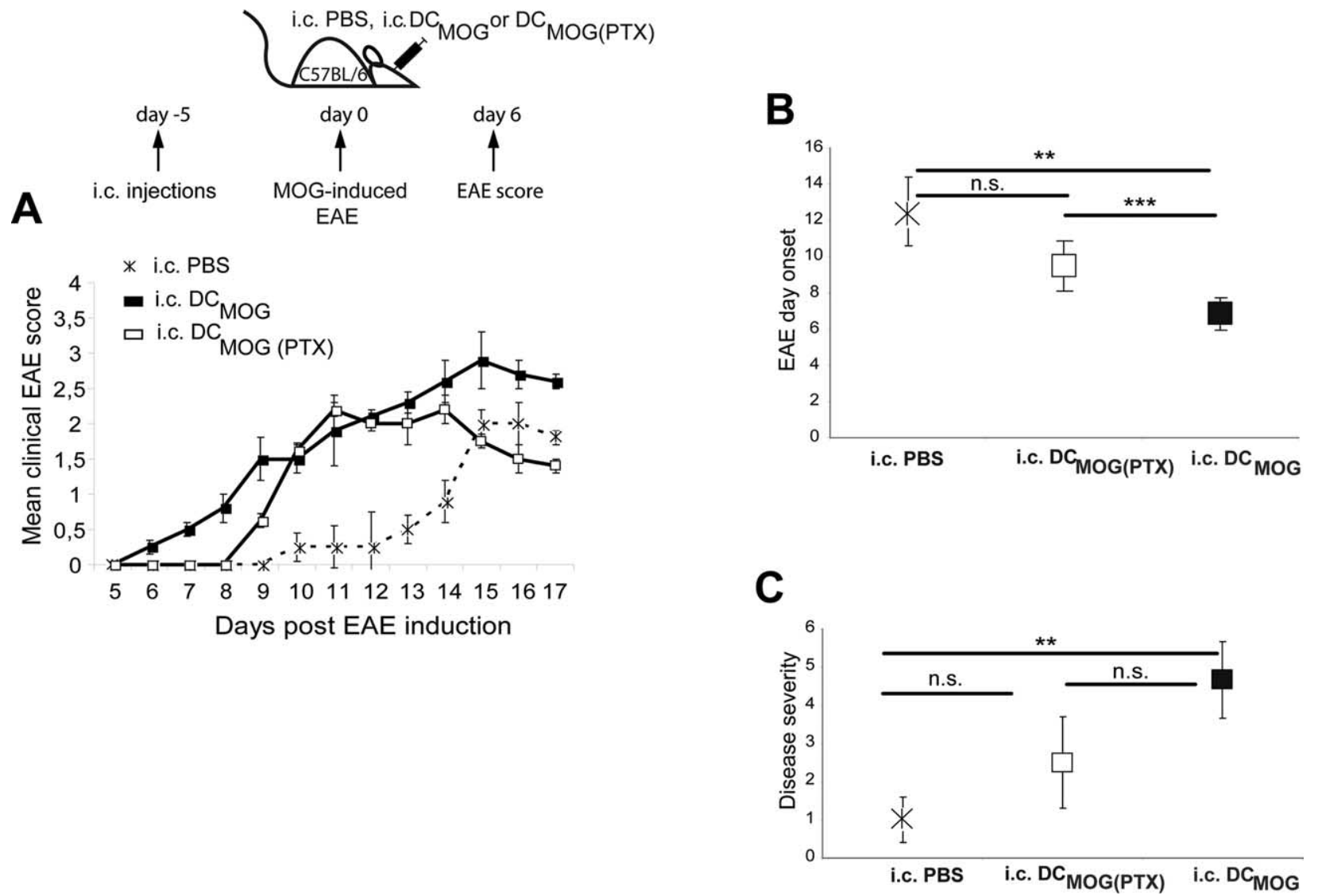

Figure 5. Pretreatment of $D C_{\text {MOG }}$ cells with PTX before their intracerebral injection does not exacerbate the onset of $E A E$. $A$, Mice were injected intracerebrally with $P B S, D C_{M O G}$, or $D C_{M O G}$ pretreated with PTX $5 \mathrm{~d}$ before EAE induction. Daily mean clinical EAE scores are shown. $B$, Graphical representation of EAE day onset for intracerebral $D C_{\text {MOG }}$ immunized animals compared with intracerebrally injected PBS and DC $C_{\text {MOG(PTX) }}$ mice. (Student's $t$ test, ${ }^{* *} p=0.008$ for intracerebral PBS compared with intracerebral $D C_{\text {MOG } ;}{ }^{* * *} p=0.0005$ for intracerebral $D C_{\text {MOG }}$ Compared with intracerebral $\left.D C_{M O G(P T X)}\right) C$, Graphical representation of the disease severity that summarizes the number of days with EAE clinical scores $\geq 2.5$ for intracerebral $D C_{M O G} C^{\circ}$ mpared with intracerebrally injected PBS and $D C_{\text {MOG(PTX) }}$ mice. (Student's $t$ test, ${ }^{* *} p=0.006$.)

lation of $\mathrm{T}$ cells in the brain contributes to the amplification of neuroinflammation during early stages of the EAE clinical course.

To address the question whether the migration of intracerebrally injected DCs out of the brain would be required to influence EAE disease onset, we inhibited the migratory capacity of DCs with PTX, blocking chemokine receptor signaling in vitro. After in vitro treatment, PTX pretreated DCs were injected into the brain. In Figure 5, we show that pretreatment of $\mathrm{DC}_{\mathrm{MOG}}$ before their intracerebral injection does not exacerbate the onset of EAE (no significant differences between intracerebral PBS vs intracerebral DC $\mathrm{MOG}_{\text {(PTX) }}$ ) (Fig. $5 A, B)$. The intracerebral $\mathrm{DC}_{\mathrm{MOG}}$ injection led to a significantly accelerated EAE clinical onset compared with both intracerebral PBS and intracerebral DC $\mathrm{MOG}_{\text {(PTX) }}$ groups (Fig. $5 A, B$ ). Furthermore, the disease severity was significantly enhanced if intracerebral PBS and intracerebral $\mathrm{DC}_{\mathrm{MOG}}$ groups were compared; however, we did not find statistical differences between intracerebral $\mathrm{DC}_{\mathrm{MOG}}$ and intracerebral DC $\mathrm{MOG}_{\mathrm{PTX})}$ groups (Fig. $5 C$ ).

Intracerebral $\mathrm{DC}_{\mathrm{MOG}}$ injection induces earlier occurrence of IFN- $\gamma$-producing MOG-specific $\mathrm{CD}^{+}{ }^{+} \mathrm{T}$ cells in the spleen during EAE

To further define the mechanisms by which intracerebral DCs regulate the early development and severity of clinical EAE symptoms, we studied the kinetics and frequency of IFN- $\gamma$-producing, MOG-specific peripheral T cells. Intracerebral delivery of $\mathrm{DC}_{\mathrm{MOG}}$ induced significantly higher numbers of IFN- $\gamma$-secreting, MOG- reactive $\mathrm{CD}^{+}{ }^{+} \mathrm{T}$ cells in the peripheral lymphoid organs (spleen) (Fig. 6) (lymph nodes) (not shown). These cells were detected earlier in the course of EAE compared with intracerebrally injected PBS animals (as measured at day 7 after EAE induction) (Fig. 6A) and also remained significantly higher at the peak of EAE (day 14) (Fig. $6 B)$. We also detected the frequency of IL-17-producing CD4 ${ }^{+} \mathrm{T}$ cells in the peripheral immune organs, which appeared to be slightly elevated in the intracerebral $\mathrm{DC}_{\mathrm{MOG}}$ compared with the intracerebral PBS group at earlier time points of EAE (day 7) (Fig. 6A) and significantly higher at later time points (day 14) (Fig. 6B). Interestingly, IFN- $\gamma$-producing $\mathrm{CD} 4{ }^{+} \mathrm{T}$ cells from cultured splenocytes isolated at different time points after EAE induction (day 7 and day 14) could also be detected in media without MOG restimulation from intracerebral $\mathrm{DC}_{\mathrm{MOG}}$, but not from intracerebrally injected PBS animals. In the clinical phase of EAE (day 14), double positive IFN- $\gamma^{+} \mathrm{IL}-17^{+} \mathrm{CD} 4{ }^{+} \mathrm{T}$ cells could also be detected in intracerebral $\mathrm{DC}_{\mathrm{MOG}}$ but not in intracerebral PBS group (Fig. $6 \mathrm{~B}$ ).

The intracerebral injection of $\mathrm{DC}_{\mathrm{MOG}}$ decreases the proportion of $\mathrm{CD} 4{ }^{+}$FoxP3-expressing cells in the brain during EAE

Growing evidence indicates a bidirectional interaction between $\mathrm{T}_{\text {reg }}$ cells and DCs (Tang and Bluestone, 2006; Tang et al., 2006). We therefore speculated that the impact of intracerebral DC modulation on CNS autoinflammation might be reflected in a change in the absolute numbers or in the ratio between encephalitogenic and regulatory $\mathrm{CD} 4{ }^{+} \mathrm{T}$ cells in the CNS. Lymphocytes isolated 


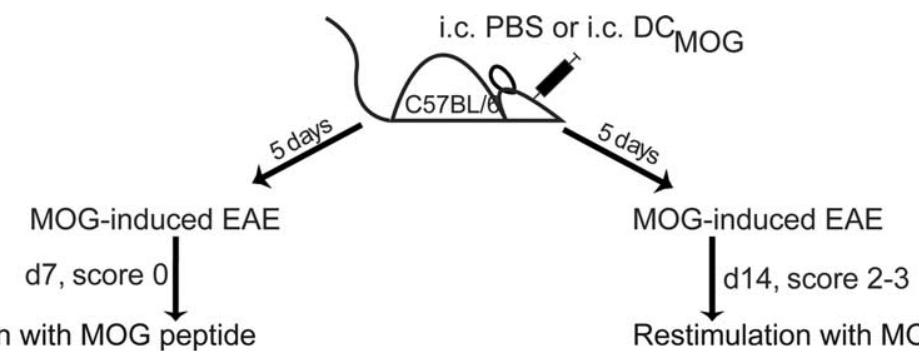

Restimulation with MOG peptide

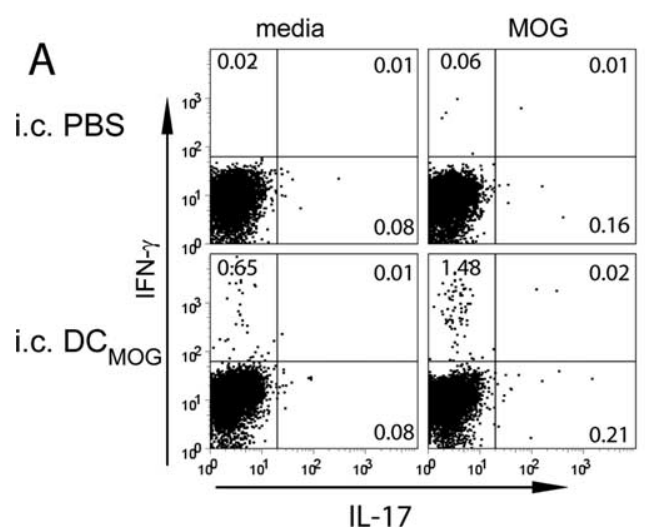

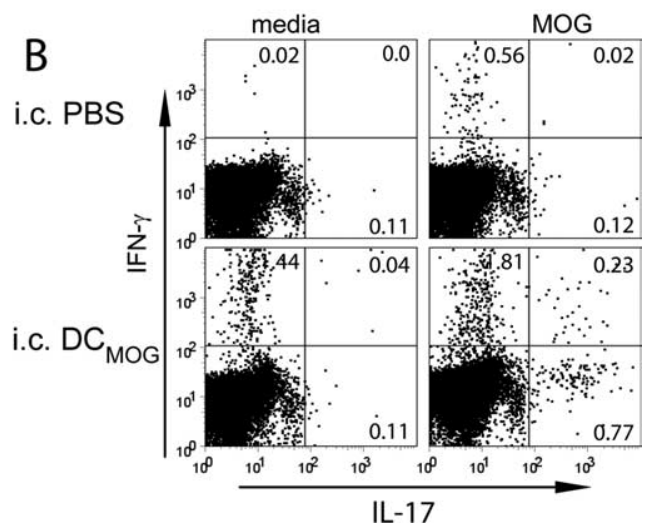

Figure 6. Exacerbation of EAE during intracerebral $D C_{\text {MOG }}$ injection is associated with increased numbers of MOG-specific IFN- $\gamma$ - and IL-17-producing CD4 ${ }^{+} T$ cells in the peripheral immune organs. $\boldsymbol{A}, \boldsymbol{B}$, Dot plots demonstrate IFN- $\gamma$ and IL-17-producing $C D 4^{+} \mathrm{T}$ cells in media or after $\mathrm{MOG}_{35-55}$ peptide restimulation $7(\boldsymbol{A})$ and $14 \mathrm{~d}(\boldsymbol{B})$ after EAE induction. Data shown are representative of seven independent experiments, each with three to four mice per group with similar outcome.

A

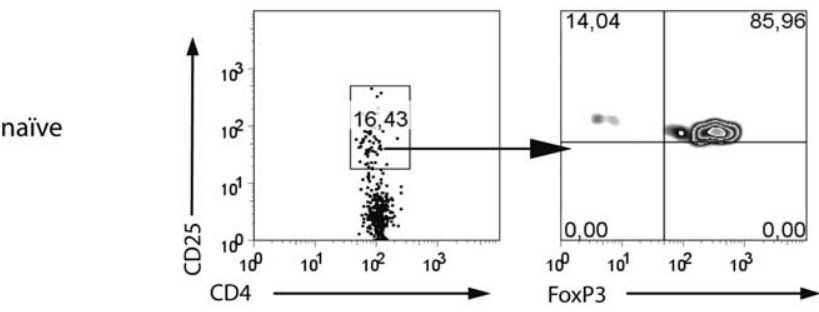

B
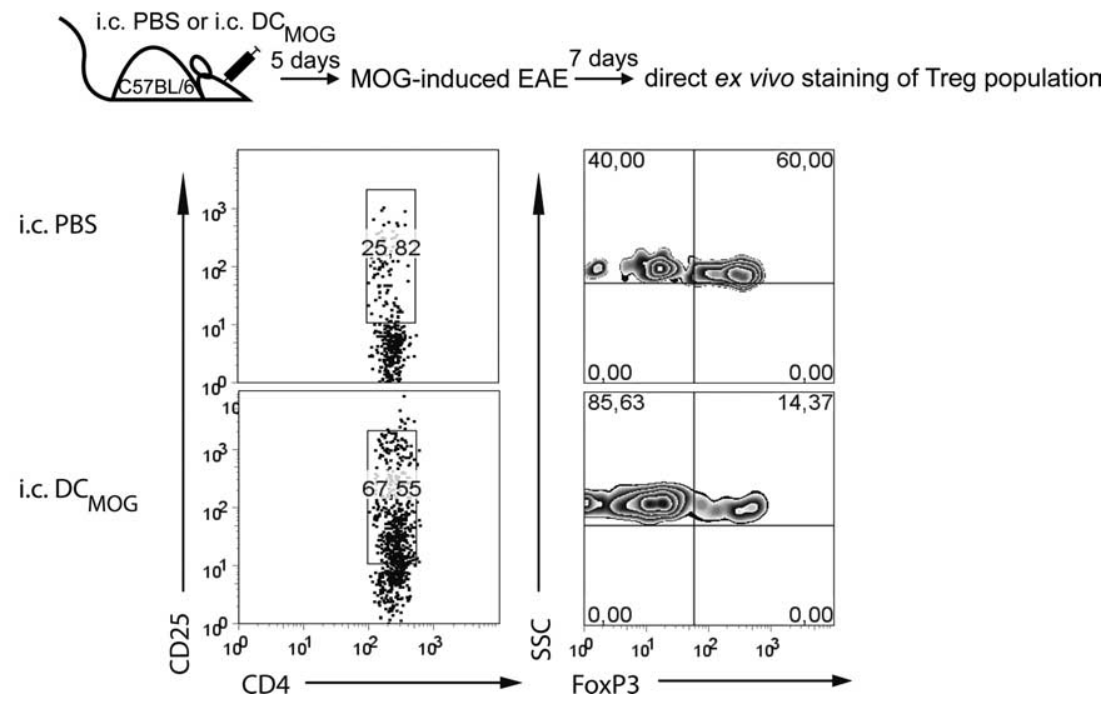

Figure 7. Intracerebral $D C_{\text {MOG }}$ injection before EAE induction results in increased numbers of $C D 4^{+} \mathrm{T}$ cells in the CNS, downregulating the number of regulatory $T$ cells at the expense of effector cells. $A, B$, The dot plots represent the percentage of $\mathrm{CD}^{+}{ }^{+} \mathrm{CD} 25^{\text {high }} \mathrm{T}$ cells (left) and the percentage of FoxP3 ${ }^{+}$regulatory $T$ cells (right) within CD25 ${ }^{\text {high }}$ population gated on CNS lymphocytes isolated from naive $(\boldsymbol{A})$ and intracerebrally injected animals ( $\boldsymbol{B}$ and experimental scheme). Data presented are representative analyses of three separate experiments, each with two mice per group. from noninflamed (naive) brains contained only a few $\mathrm{CD} 4{ }^{+} \mathrm{T}$ cells that predominantly exhibited the FoxP $3^{\text {high }}$ regulatory phenotype (Fig. 7A). The expression of FoxP3 on $\mathrm{CD} 4{ }^{+} \mathrm{CD} 25^{\text {high }}$ cells was clearly decreased in the brain of intracerebrally injected DCMOG animals (Fig. $7 B$, bottom) compared with intracerebrally injected PBS control group (Fig. $6 B$, top). This data show that in parallel with early EAE onset and higher accumulation of MOG-specific $T$ cells after intracerebral $\mathrm{DC}_{\mathrm{MOG}}$ injection, the frequency of FoxP3 ${ }^{\text {high }}$ cells in the brain is decreased, and intracerebral $\mathrm{DC}_{\mathrm{MOG}}$ alters the ratio between encephalitogenic and regulatory $\mathrm{T}$ cells.

Intracerebral injection of TNF- $\alpha$ treated, semimature DCs ameliorates EAE by inducing peripheral IL-10secreting cells and restricting the CNS from IL-17-producing $\mathrm{CD} 4^{+} \mathrm{T}$ cells It has been proposed that CNS DCs have a dual role during EAE, as they could provide stimulatory or suppressive signals at different stages of disease (Deshpande et al., 2007). Modifying DC phenotypes with TNF- $\alpha$ elicits the generation of IL-10producing $\mathrm{T}$ cells and leads to antigenspecific prevention of EAE (Menges et al., 2002) (for review, see Steinman et al., 2003). We therefore asked the question whether the functional state of intracerebral DCs is decisive for the qualitative and 

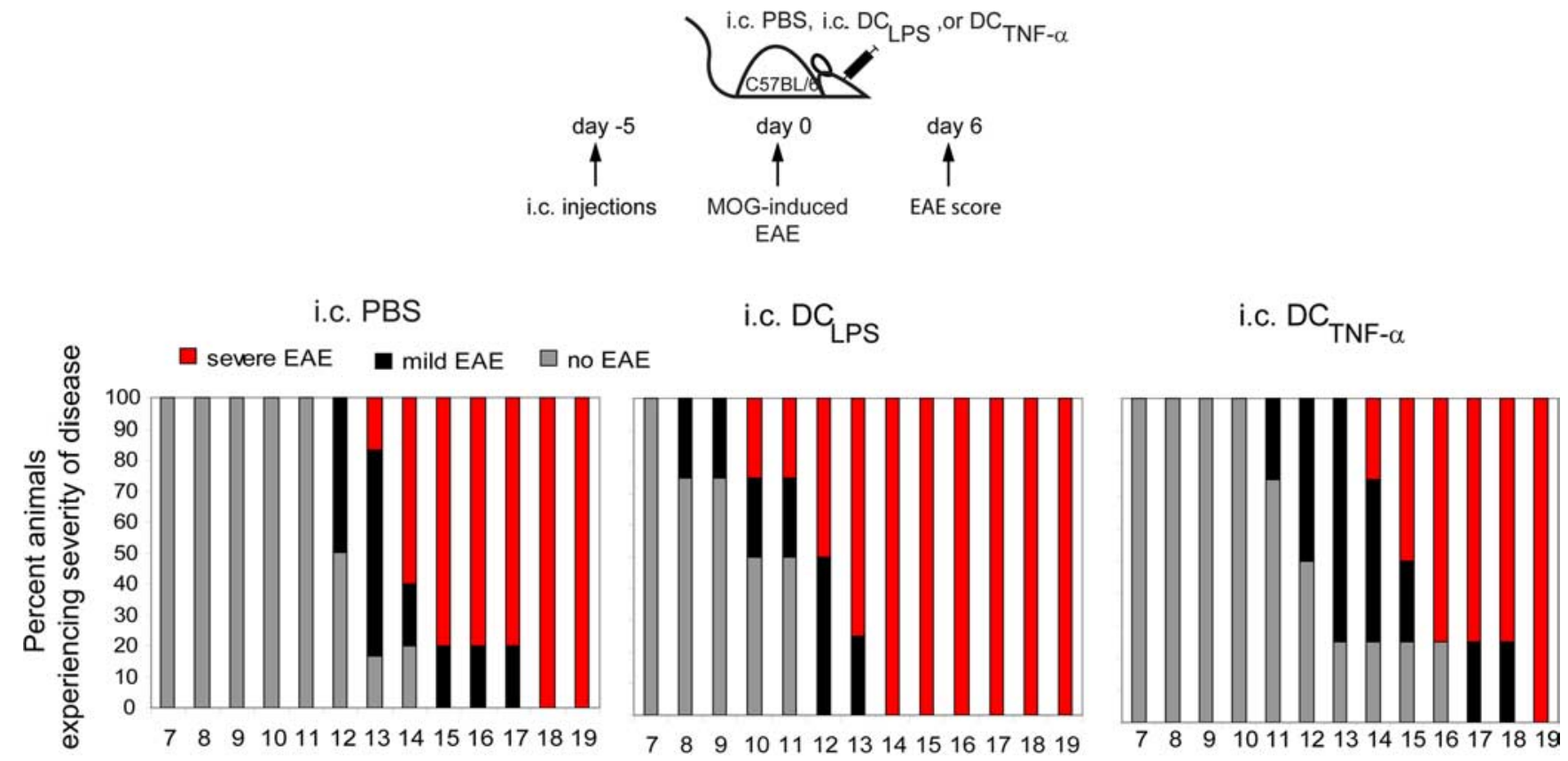

Days post EAE induction

Figure 8. Intracerebral injection of TNF- $\alpha$ treated, semimature $D C S\left(D C_{\text {TNF- } \alpha}\right.$ ) ameliorates EAE. DCs modified by TNF- $\alpha\left(D C_{\text {TNF- } \alpha}\right)$ or LPS (DC $\left.C_{\text {LPS }}\right)$ were pulsed with MOG and intracerebrally injected into mice before EAE induction. The intracerebral PBS, intracerebral $D_{\mathrm{TNF}^{\prime} \alpha^{\prime}}$ or intracerebral $D C_{\mathrm{LPs}}$ injections were followed with active EAE induction $5 \mathrm{~d}$ after intracerebral injections. The mice were observed for EAE clinical scores over time. Graphical representation shows the proportion of mice in three groups on each day experiencing no onset or no clinical symptoms (gray portion of bar), mild EAE (black portion of bar), or severe EAE (red portion of bar).

Table 2. Effect of tolerogenic and stimulatory intracerebral immunizations of DC on EAE induction

\begin{tabular}{|c|c|c|c|c|}
\hline Immunization & $\begin{array}{l}\text { Incidence } \\
(\%)\end{array}$ & $\begin{array}{l}\text { No. } \\
\text { of mice }\end{array}$ & $\begin{array}{l}\text { Mean } \\
\text { day onset }\end{array}$ & $\begin{array}{l}\text { Mean } \\
\text { maximal score }\end{array}$ \\
\hline Intracerebral PBS + subcutaneous CFA-MOG & 77 & 17 of 22 & $14.0 \pm 3$ & $2.52 \pm 1.0$ \\
\hline Intracerebral $\mathrm{DC}_{\mathrm{TNF}-\alpha}+$ subcutaneous CFA-MOG & 35 & 6 of 17 & $14.0 \pm 2$ & $2.17 \pm 1.1^{a}$ \\
\hline Intracerebral DC $C_{\text {LPS }}+$ subcutaneous CFA-MOG & 100 & 9 of 9 & $10.0 \pm 2^{*}$ & $2.88 \pm 0.5^{* a}$ \\
\hline
\end{tabular}

${ }^{a} p$ values are compared with intracerebral $\mathrm{PBS}$ and intracerebral $\mathrm{DC} \mathrm{TNF}-\alpha[\rho]$.

${ }^{*} p<0.05$; Student's $t$ test.

quantitative outcome of experimental CNS inflammation. We injected MOG-pulsed and TNF- $\alpha$ - or LPS-treated (DC $\mathrm{DNF}_{\mathrm{TN}}$ or $\mathrm{DC}_{\mathrm{LPS}}$ ) semimature DCs intracerebrally and subsequently induced EAE. Among other microbial products, LPS treatment results in an upregulation of maturation markers and an increase in the ability of DCs to stimulate T cells (for review, see Reis e Sousa, 2006). Intracerebrally injected $D_{\text {LPS }}$ significantly exacerbated EAE onset and increased EAE severity compared with intracerebrally injected PBS animals (Fig. 8; Table 2). Intracerebral injection of $\mathrm{DC}_{\mathrm{TNF}-\alpha}$ beneficially modulated EAE compared with the intracerebrally injected $\mathrm{DC}_{\mathrm{LPS}}$ group. Protection ranged from delaying disease onset to full prevention of clinical symptoms (only $35 \%$ disease incidence) (Fig. 8; Table 2). Onset of EAE clinical symptoms was on average 3-4 d later in intracerebrally injected $\mathrm{DC}_{\mathrm{TNF}-\alpha}$ and PBS mice compared with intracerebrally injected $\mathrm{DC}_{\mathrm{LPS}}$ animals. Also, the severity of disease after onset was lower in intracerebrally injected $\mathrm{DC}_{\mathrm{TNF}-\alpha}$ groups compared with intracerebrally injected $\mathrm{DC}_{\mathrm{LPS}}$ groups. To assess the mechanism of how intracerebral $\mathrm{DC}_{\mathrm{TNF}-\alpha}$ injections promoted $\mathrm{EAE}$ protection, we measured the frequency and function of peripheral and CNSinfiltrating immune cells in intracerebrally injected $\mathrm{DC}_{\mathrm{TNF}-\alpha}$, $\mathrm{DC}_{\text {LPS }}$, and PBS mice. Although clinical disease was delayed or EAE was ameliorated (Fig. 8; Table 2), intracerebrally injected $\mathrm{DC}_{\mathrm{TNF}-\alpha}$ EAE mice did not have decreased numbers of CNS in- filtrating $\mathrm{CD}^{+}{ }^{+}$and $\mathrm{CD} 8{ }^{+}$T cells at any time points (Fig. $9 A, B$ ). The ratio of encephalitogenic to regulatory $\mathrm{T}$ cells was higher in intracerebrally injected $\mathrm{DC}_{\mathrm{LPS}}$ and $\mathrm{DC}_{\mathrm{TNF}-\alpha}$ groups compared with intracerebrally injected PBS mice, similar to that observed between intracerebrally injected $\mathrm{DC}_{\mathrm{MOG}}$ and $\mathrm{PBS}$ groups (Fig. 7) (data not shown). We observed a higher accumulation of $\mathrm{CD} 45^{+} \mathrm{CD} 11 \mathrm{~b}$ high macrophages in intracerebrally injected $\mathrm{DC}_{\mathrm{LPS}}$ mice and similar subsets of $\mathrm{CD} 45^{+} \mathrm{CD} 11 \mathrm{~b}$ high macrophages and $\mathrm{CD} 45^{+} \mathrm{CD} 11 \mathrm{~b}^{\text {low }}$ microglia in intracerebrally injected PBS and $\mathrm{DC}_{\mathrm{TNF}-\alpha}$ groups (Fig. 9A). Similar to intracerebrally injected $\mathrm{DC}_{\mathrm{MOG}}$ animals (Fig. 4), CD ${ }^{+} \mathrm{T}$ cells persisted at later stages of EAE (day 17) in intracerebrally injected $\mathrm{DC}_{\mathrm{TNF}-\alpha}$ and $\mathrm{DC}_{\mathrm{LPS}}$ groups compared with intracerebral PBS controls (Fig. 9B). To find factors that may be responsible for earlier EAE onset (intracerebral $\mathrm{DC}_{\mathrm{LPS}}$ ) or a delay in EAE onset (intracerebral $\left.\mathrm{DC}_{\mathrm{TNF}-\alpha}\right)$ at earlier time points of disease, we measured the cytokines produced both in the CNS and periphery at different stages of EAE. Notably, lymphocytes isolated from the CNS of intracerebrally injected $\mathrm{DC}_{\mathrm{TNF}-\alpha}$ and $\mathrm{DC}_{\mathrm{LPS}}$ mice produced comparable levels of IL-10 at earlier (day 7) and later (day 17) time points, which were higher compared with intracerebrally injected PBS animals (Fig. 9C,D, left panels). Although there was no IFN- $\gamma$ signal detected in the CNS for intracerebrally injected PBS animals, $962 \mathrm{pg} / \mathrm{ml}$ of IFN- $\gamma$ was detected in intracerebral $\mathrm{DC}_{\mathrm{LPS}}$ 


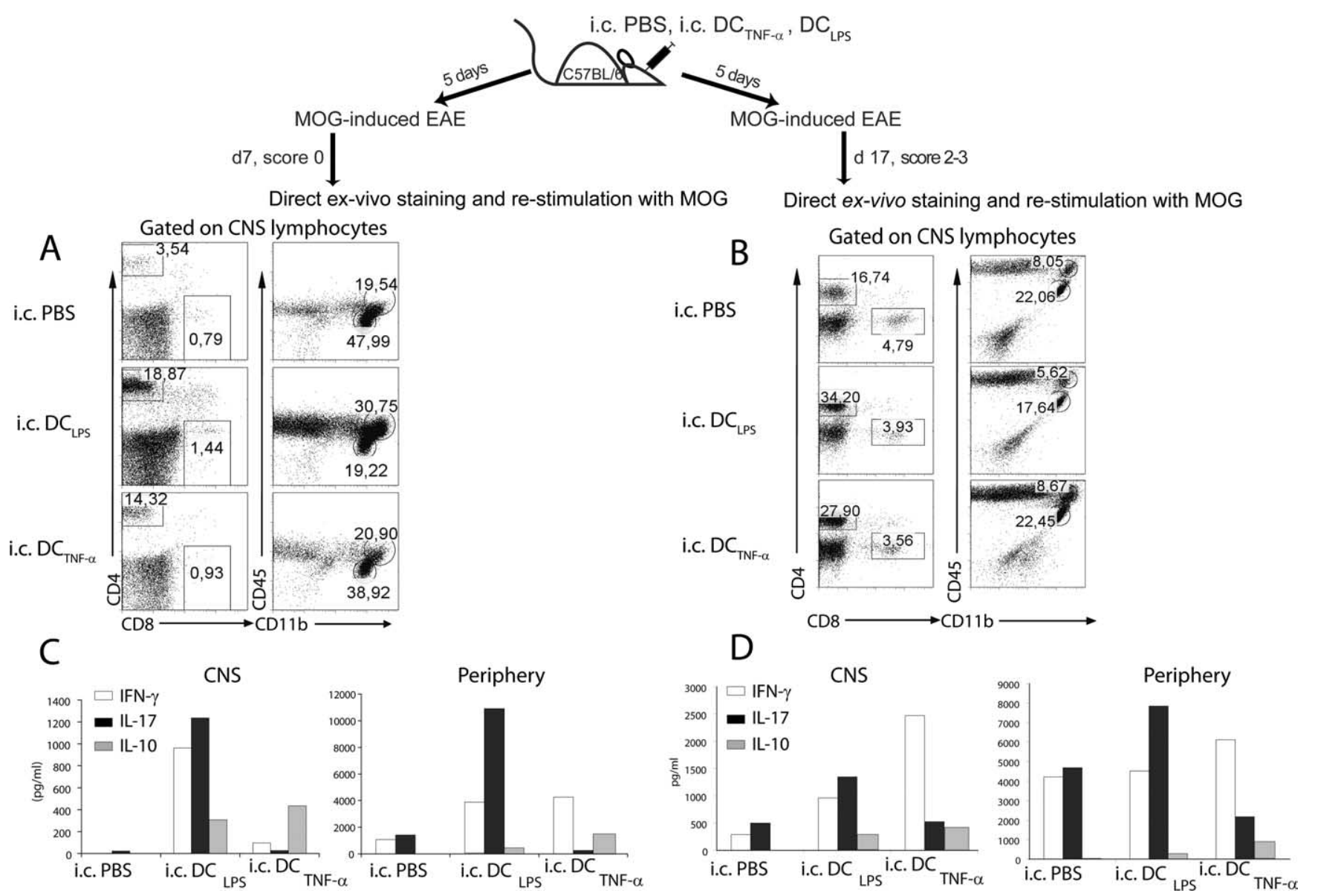

Figure 9. MOG-loaded and intracerebrally injected $D C_{\mathrm{LPS}}$ and $D C_{\mathrm{TNF}-\alpha}$ induce similar infiltration of leukocytes into the brain but result in different cytokine profiles in the $C N \mathrm{NS}_{\text {and }}$ periphery. $\boldsymbol{A}, \boldsymbol{B}$, Intracerebrally injected $P B S, D C_{L P S}$ or $D C_{\text {TNF- } \alpha}$ groups of injected mice were analyzed for leukocyte infiltration before EAE onset $(\boldsymbol{A})$ and at the later phase of EAE ( $\left.\boldsymbol{B}\right)$. Plots are gated for infiltration of $\mathrm{CD} 4^{+}$and $\mathrm{CD} 8{ }^{+} \mathrm{T}$ cells (left) and $\mathrm{CD} 45^{+} \mathrm{CD} 11 \mathrm{~b}^{\text {high }}$ macrophages and $\mathrm{CD} 45^{+} \mathrm{CD} 11 \mathrm{~b}^{\text {low }}$ microglia (right). C, D, Cytokine bead array of secreted cytokines in culture supernatants of CNS lymphocytes and splenocytes collected after $48 \mathrm{~h}$ of restimulation with $\mathrm{MOG}_{35-55}$ peptide. The amount of IFN- $\gamma$, IL-17 and IL-10-producing cells in response to $\mathrm{MOG}$ restimulation at day 7 (C) and day 17 (D) after EAE induction. Data collected are from two separate experiments with CNS cells isolated from two to four mice and pooled.

group, which was 10-fold higher than the concentration of IFN- $\gamma$ in intracerebral $\mathrm{DC}_{\mathrm{TNF}-\alpha}$ mice $(95 \mathrm{pg} / \mathrm{ml}$ ) before EAE onset (day 7 after EAE induction). At this point, intracerebral $\mathrm{DC}_{\mathrm{TNF}-\alpha} \mathrm{Com}-$ pletely protected both the CNS compartment and peripheral immune organs from IL-17-producing cells $(26 \mathrm{pg} / \mathrm{ml}$ and $263 \mathrm{pg}$ / $\mathrm{ml}$, respectively) compared with the intracerebrally injected $\mathrm{DC}_{\text {LPS }}$ group (1235 pg/ml and $10910 \mathrm{pg} / \mathrm{ml}$, respectively) (Fig. 9C). At later time points of EAE (day 17), the intracerebrally injected $\mathrm{DC}_{\mathrm{LPS}}$ group contained cells with a phenotype polarized toward Th-17 profile with $1350 \mathrm{pg} / \mathrm{ml}$ of IL-17 in the CNS and $7841 \mathrm{pg} / \mathrm{ml}$ of IL-17-producing cells in the periphery (spleen), which was twofold higher than IL-17 production detected in intracerebrally injected $\mathrm{DC}_{\mathrm{TNF}-\alpha}$ and PBS mice in the CNS and periphery (Fig. 9D). However, a great majority of CNS lymphocytes in intracerebrally injected $\mathrm{DC}_{\mathrm{TNF}-\alpha}$ mice included IFN- $\gamma$ producing cells $\left(2468 \mathrm{pg} / \mathrm{ml}\right.$ of IFN- $\gamma$ in intracerebral $\mathrm{DC}_{\mathrm{TNF}-\alpha}$ compared with $962 \mathrm{pg} / \mathrm{ml}$ in intracerebral DC $_{\text {LPS }}$ mice), suggesting a Th1 phenotype in this group at later time points of EAE (day 17). At the same time, intracerebral $\mathrm{DC}_{\mathrm{TNF}-\alpha}$ injections induced a higher amount of peripheral IL-10 production after both 7 and $17 \mathrm{~d}$ after EAE induction compared with the intracerebral $\mathrm{DC}_{\mathrm{LPS}}$ group (Fig. 9C,D).

These data indicate that TNF- $\alpha$-treated, MOG-pulsed DCs injection into the brain induces a predominantly IL-10 domi- nated peripheral immune response that restrains Th17-mediated pathology during EAE.

\section{Discussion}

DCs have emerged as pivotal regulators of CNS autoimmune and inflammatory responses. Taking advantage of the targeted intracerebral microinjection technology, combined with methods to generate stimulatory or inhibitory tolerogenic DCs, we have analyzed the role of functionally different DCs on the generation of neuroantigen-specific immune responses and their relevance for modulating experimental neuroinflammation using the mouse model of $\mathrm{MOG}_{35-55}$-induced EAE.

Our results demonstrate that immunogenic DCs pulsed with MOG antigen and injected into the brain (intracerebral $\mathrm{DC}_{\mathrm{MOG}}$ ) activated naive antigen-specific $\mathrm{T}$ cells in peripheral immune organs and promoted CNS invasion of neuroantigen-specific $\mathrm{CD}^{+}{ }^{+} \mathrm{T}$ cells. However, the intracerebral $\mathrm{DC}_{\mathrm{MOG}}$ did not induce EAE if injected without active immunization. This implies that peripheral induction for the disease is necessary. In this model, a mixture of MOG and CFA needs to be delivered subcutaneously to induce EAE, and in this case, the intracerebral $\mathrm{DC}_{\mathrm{MOG}}$ accelerated EAE initiation. Together, this may suggest that peripheral antigen presentation and immunization are necessary and sufficient to induce EAE and that intracerebral $\mathrm{DC}_{\mathrm{MOG}}$ can only mod- 
ify the kinetics of disease. Thus, the main role of DCs in the brain appears to be in the effector phase of the immune response, rather than in the priming phase. The increasing number of MOGloaded stimulatory DCs in the brain also accelerated the onset of EAE disease and resulted in exacerbated clinical severity and the extent of the disease. This was accompanied by an early infiltration of IFN- $\gamma$-producing MOG-reactive $\mathrm{CD} 4{ }^{+} \mathrm{T}$ cells from the periphery into the CNS and a decrease in the proportion of FoxP3-expressing $\mathrm{CD}{ }^{+}$regulatory $\mathrm{T}$ cells, suggesting a shift toward the enrichment of encephalitogenic $\mathrm{T}$ cells. In contrast, intracerebral injection of TNF- $\alpha$-treated and MOG-loaded tolerogenic dendritic cells (intracerebral $\mathrm{DC}_{\mathrm{TNF}-\alpha}$ ) before EAE induction prevented clinical signs of EAE disease (35\% disease incidence) or delayed EAE onset, followed by decreased IL-17 production in the CNS and increased level of IL-10-producing peripheral and CNS CD $4{ }^{+}$T cells.

Recently, several studies have contributed to the notion that antigen-presenting cells in the brain play a key role in determining the outcome of CNS inflammation (Greter et al., 2005; McMahon et al., 2005; Bailey et al., 2007). Under inflammatory conditions (e.g., autoimmunity and infectious disease), DCs accumulate in the CNS parenchyma, suggesting that CNS DCs are critical for the initiation, regulation, and/or maintenance of immune responses in the CNS. Although numerous studies unambiguously emphasize the potential relevance of DCs for CNS immune surveillance or autoimmune reactions, the true contribution of DCs in the initiation and perpetuation of neuroantigen-specific T-cell responses remains elusive. Our work tested the relevance and impact of CNS-derived DCs by taking advantage of a DC delivery method into the CNS. We found that the activation and CNS accumulation of neuroantigen-specific $\mathrm{T}$ cells critically depended on the route of MOG antigen delivery by DCs and the site of DC origin. Local brain DCs are likely to provide critical signals for attracting antigen-specific CD ${ }^{+}$and $\mathrm{CD} 8{ }^{+} \mathrm{T}$ cells into the inflamed CNS (Carson et al., 1999; Tang and Cyster, 1999). A combination of different cytokines, chemokines and inflammatory mediators might be responsible for the regulation of local inflammatory responses via intracerebral DCs. At the same time, several chemokines such as MIP-1 $\alpha$ (CCL3), MIP-3 $\beta$ (CCL20), MCP-1 (CCL2), and RANTES (CCL5) are produced in the CNS during acute and chronic EAE (Serafini et al., 2000; Bailey et al., 2007). Defined by chemokine responsiveness, DC populations can differentially migrate to CNS compartments (Bailey et al., 2007). Myeloid DCs were recently shown to preferentially accumulate in the perivascular inflammatory foci of the spinal cord and cerebellum, clustering there with T cells at the peak of EAE (Bailey et al., 2007). The establishment of such DC-T and DC-B cell clusters in the CNS may be necessary to sustain intrathecal clonal expansion of $\mathrm{T}$ cells and production of anti-myelin-specific antibodies as detected in EAE and MS lesions.

Spatial CNS localization of MOG antigen-pulsed DCs is critical in the accumulation of antigen-specific T cells in the brain. To further strengthen the importance of specific antigen presentation by intracerebral DCs, we performed experiments directly in 2D2 mice. We show that intracerebral $\mathrm{DC}_{\mathrm{MOG}}$ injection significantly increased MOG-specific CD $4^{+} \mathrm{V} \beta 11^{+}$T-cell accumulation in the CNS (4.2 vs $21.15 \%$ ). Unpulsed DC injection into the brain induced a detectable accumulation of neuroantigenspecific cells in the brain under these experimental conditions, which might be attributable to the intrinsic ability of intracerebral DCs to pick up local CNS antigen and present it to naive $\mathrm{T}$ cells, resulting in their expansion.
Severity of EAE as well as the number of MS plaques seem to correlate with the presence and function of DCs (Pashenkov et al., 2001; Greter et al., 2005; Serafini et al., 2006). One of the most important observations from our studies is that the amount of DCs in the brain could be a limiting factor in CNS autoimmune diseases. Our data show that in the early phase of EAE autoimmune disease, the number of DCs in the brain is critical, and this is a rate-limiting factor for the development of the disease. This and other studies (Greter et al., 2005; McMahon et al., 2005) collectively suggest that CNS-associated DCs are capable of inducing pathogenetically relevant $\mathrm{T}$-cell responses locally in the brain.

Some data indicate that regulatory $\mathrm{T}$ cells are critical in the maintenance of immune privilege status of the CNS (Korn et al., 2007; O'Connor et al., 2007). We investigated the influence of intracerebral $\mathrm{DC}_{\mathrm{MOG}}$ injections on FoxP3 $\mathrm{T}_{\text {reg }}$ accumulation in the CNS. Although the naive brain per se contained a very low number of $\mathrm{CD} 4{ }^{+} \mathrm{T}$ cells, the majority of these cells expressed high levels of FoxP3. This might indicate that the high level of FoxP3 cells in the brain could be a part of the mechanisms maintaining an "immunological privileged" milieu of the CNS. Our experiments show that intracerebral DC injections induce the CNS accumulation of FoxP3 negative neuroantigen-specific $\mathrm{T}$ cells, which occurs at the expense of FoxP3 $\mathrm{T}_{\text {reg }}$ cells. Thus, immunogenic DCs clearly alter the ratio of encephalitogenic to regulatory $\mathrm{T}$ cells. Whether regulatory $\mathrm{T}$ cells play a critical role in modifying CNS autoimmunity needs to be further studied (Zozulya and Wiendl, 2008).

DCs with regulatory or tolerogenic properties are capable of attenuating EAE (for review, see Miller et al., 2007a). It was previously demonstrated that $\mathrm{DC}_{\mathrm{MOG}}$ matured with TNF- $\alpha$ and systemically injected into mice before EAE induction induced antigen-specific protection from EAE in mice (Menges et al., 2002). Here, we show that semimature DCs have a protective effect on subsequent CNS-directed autoimmune responses, emphasizing the notion that the functional state of DCs has a clear impact on the quantity and quality of CNS-directed immune responses. The mechanism of EAE-attenuation by tolerogenic TNF- $\alpha$-matured DCs is noteworthy. Strikingly, absolute numbers of CNS-infiltrating immune cells are equally high in animals receiving intracerebral injections of $\mathrm{DC}_{\mathrm{TNF}-\alpha}$ or $\mathrm{DC}_{\mathrm{LPS}}$. Although we did not test the production of cytokines by CNS DCs in this study, it is well known that multiple immune mediators can be produced by DCs. It was proposed that DCs can polarize CD ${ }^{+} \mathrm{T}$ cells to become either Th17 or Th1 cells, producing IL-17 or IFN- $\gamma$, respectively. Tolerogenic or stimulatory DCs influence this polarization differently (Shortman and Liu, 2002; Shortman and Naik, 2007). Thus, IL-17 polarized CNS T cells with pathological function in the relapsing EAE model, and their clustering with myeloid DCs in the CNS indicate the latter as the only CNS APC population that biased antigen-specific $\mathrm{T}$ cells toward a Th17 profile (Bailey et al., 2007). Endogenously collecting CNS antigen and highly producing IL- 6 and TGF- $\beta$, DCs polarized Th17 responses which could be an intrinsic property of myeloid DCs or the CNS environment (Bailey et al., 2007; Miller et al., 2007b). Our data show that intracerebral injection of $\mathrm{DC}_{\mathrm{TNF}-\alpha}$ completely protects the CNS from infiltration of IL-17producing cells but promotes IL-10 cells both in the CNS and in the periphery at early time points of EAE. This supports the idea that CNS DCs, depending on their functional state, can accelerate IL-17 appearance, leading to earlier EAE onset or restrict IL-17 generation in the target organ, thus delaying the disease.

In summary, our study shows that intracerebral DCs are ca- 
pable of mounting CNS-specific T-cell responses and, in contrast to peripheral DCs, of inducing specific accumulation of neuroantigen-specific $\mathrm{T}$ cells in the brain. The quantity of stimulatory DCs in the CNS is a rate-limiting factor for the onset of subsequent EAE. Furthermore, the functional state of intracerebral DCs is decisive for the outcome of a subsequent autoimmune CNS inflammation: the presence of tolerogenic DCs in the brain protects from early development of EAE clinical signs by inducing IL-10 and restricting CNS-infiltrating IL-17 cells. Intracerebral DCs can therefore be considered as a crucial immune cell population during CNS-specific immune responses and can change the outcome of autoimmune inflammatory CNS disorders. This has clear implications for understanding the pathogenesis of MS and considering DCs as potential targets for future therapies.

\section{References}

Aloisi F, Ria F, Adorini L (2000) Regulation of T-cell responses by CNS antigen-presenting cells: different roles for microglia and astrocytes. Immunol Today 21:141-147.

Ambrosini E, Remoli ME, Giacomini E, Rosicarelli B, Serafini B, Lande R, Aloisi F, Coccia EM (2005) Astrocytes produce dendritic cell-attracting chemokines in vitro and in multiple sclerosis lesions. J Neuropathol Exp Neurol 64:706-715.

Bailey SL, Schreiner B, McMahon EJ, Miller SD (2007) CNS myeloid DCs presenting endogenous myelin peptides 'preferentially' polarize $\mathrm{CD} 4+$ $\mathrm{T}(\mathrm{H})-17$ cells in relapsing EAE. Nat Immunol 8:172-180.

Becher B, Bechmann I, Greter M (2006) Antigen presentation in autoimmunity and CNS inflammation: how T lymphocytes recognize the brain. J Mol Med 84:532-543.

Bettelli E, Pagany M, Weiner HL, Linington C, Sobel RA, Kuchroo VK (2003) Myelin oligodendrocyte glycoprotein-specific T cell receptor transgenic mice develop spontaneous autoimmune optic neuritis. J Exp Med 197:1073-1081.

Carson MJ, Reilly CR, Sutcliffe JG, Lo D (1999) Disproportionate recruitment of CD8 + T cells into the central nervous system by professional antigen-presenting cells. Am J Pathol 154:481-494.

Deshpande P, King IL, Segal BM (2007) Cutting edge: CNS CD11c+ cells from mice with encephalomyelitis polarize Th17 cells and support $\mathrm{CD} 25+\mathrm{CD} 4+\mathrm{T}$ cell-mediated immunosuppression, suggesting dual roles in the disease process. J Immunol 178:6695-6699.

Dittel BN, Visintin I, Merchant RM, Janeway CA Jr (1999) Presentation of the self antigen myelin basic protein by dendritic cells leads to experimental autoimmune encephalomyelitis. J Immunol 163:32-39.

Fischer HG, Bielinsky AK (1999) Antigen presentation function of brainderived dendriform cells depends on astrocyte help. Int Immunol 11:1265-1274.

Fischer HG, Reichmann G (2001) Brain dendritic cells and macrophages/ microglia in central nervous system inflammation. J Immunol 166:2717-2726.

Fischer HG, Bonifas U, Reichmann G (2000) Phenotype and functions of brain dendritic cells emerging during chronic infection of mice with Toxoplasma gondii. J Immunol 164:4826-4834.

Fleming KK, Bovaird JA, Mosier MC, Emerson MR, LeVine SM, Marquis JG (2005) Statistical analysis of data from studies on experimental autoimmune encephalomyelitis. J Neuroimmunol 170:71-84.

Greenwood J, Amos CL, Walters CE, Couraud PO, Lyck R, Engelhardt B, Adamson P (2003) Intracellular domain of brain endothelial intercellular adhesion molecule-1 is essential for T lymphocyte-mediated signaling and migration. J Immunol 171:2099-2108.

Greter M, Heppner FL, Lemos MP, Odermatt BM, Goebels N, Laufer T, Noelle RJ, Becher B (2005) Dendritic cells permit immune invasion of the CNS in an animal model of multiple sclerosis. Nat Med 11:328 -334.

Hanly A, Petito CK (1998) HLA-DR-positive dendritic cells of the normal human choroid plexus: a potential reservoir of HIV in the central nervous system. Hum Pathol 29:88-93.

Inaba K, Inaba M, Romani N, Aya H, Deguchi M, Ikehara S, Muramatsu S, Steinman RM (1992) Generation of large numbers of dendritic cells from mouse bone marrow cultures supplemented with granulocyte/macrophage colony-stimulating factor. J Exp Med 176:1693-1702.
Juedes AE, Ruddle NH (2001) Resident and infiltrating central nervous system APCs regulate the emergence and resolution of experimental autoimmune encephalomyelitis. J Immunol 166:5168-5175.

Karman J, Ling C, Sandor M, Fabry Z (2004a) Initiation of immune responses in brain is promoted by local dendritic cells. J Immunol 173:2353-2361.

Karman J, Ling C, Sandor M, Fabry Z (2004b) Dendritic cells in the initiation of immune responses against central nervous system-derived antigens. Immunol Lett 92:107-115.

Karman J, Chu HH, Co DO, Seroogy CM, Sandor M, Fabry Z (2006) Dendritic cells amplify $\mathrm{T}$ cell-mediated immune responses in the central nervous system. J Immunol 177:7750-7760.

Kivisäkk P, Mahad DJ, Callahan MK, Sikora K, Trebst C, Tucky B, Wujek J, Ravid R, Staugaitis SM, Lassmann H, Ransohoff RM (2004) Expression of CCR7 in multiple sclerosis: implications for CNS immunity. Ann Neurol 55:627-638.

Kleindienst P, Wiethe C, Lutz MB, Brocker T (2005) Simultaneous induction of CD4 T cell tolerance and CD8 T cell immunity by semimature dendritic cells. J Immunol 174:3941-3947.

Korn T, Reddy J, Gao W, Bettelli E, Awasthi A, Petersen TR, Bäckström BT, Sobel RA, Wucherpfennig KW, Strom TB, Oukka M, Kuchroo VK (2007) Myelin-specific regulatory T cells accumulate in the CNS but fail to control autoimmune inflammation. Nat Med 13:423-431.

Lahl K, Loddenkemper C, Drouin C, Freyer J, Arnason J, Eberl G, Hamann A, Wagner H, Huehn J, Sparwasser T (2007) Selective depletion of Foxp3 + regulatory T cells induces a scurfy-like disease. J Exp Med 204:57-63.

Lauterbach H, Zuniga EI, Truong P, Oldstone MB, McGavern DB (2006) Adoptive immunotherapy induces CNS dendritic cell recruitment and antigen presentation during clearance of a persistent viral infection. J Exp Med 203:1963-1975.

Ling C, Sandor M, Fabry Z (2003) In situ processing and distribution of intracerebrally injected OVA in the CNS. J Neuroimmunol 141:90-98.

Ling C, Sandor M, Suresh M, Fabry Z (2006) Traumatic injury and the presence of antigen differentially contribute to T-cell recruitment in the CNS. J Neurosci 26:731-741.

Marriott I, Inscho EW, Bost KL (1999) Extracellular uridine nucleotides initiate cytokine production by murine dendritic cells. Cell Immunol 195:147-156.

Matyszak MK, Perry VH (1996) The potential role of dendritic cells in immune-mediated inflammatory diseases in the central nervous system. Neuroscience 74:599-608

McMahon EJ, Bailey SL, Castenada CV, Waldner H, Miller SD (2005) Epitope spreading initiates in the CNS in two mouse models of multiple sclerosis. Nat Med 11:335-339.

McMahon EJ, Bailey SL, Miller SD (2006) CNS dendritic cells: critical participants in CNS inflammation? Neurochem Int 49:195-203.

McMenamin PG (1999) Distribution and phenotype of dendritic cells and resident tissue macrophages in the dura mater, leptomeninges, and choroid plexus of the rat brain as demonstrated in wholemount preparations. J Comp Neurol 405:553-562.

Menges M, Rössner S, Voigtländer C, Schindler H, Kukutsch NA, Bogdan C, Erb K, Schuler G, Lutz MB (2002) Repetitive injections of dendritic cells matured with tumor necrosis factor alpha induce antigen-specific protection of mice from autoimmunity. J Exp Med 195:15-21.

Miller SD, Turley DM, Podojil JR (2007a) Antigen-specific tolerance strategies for the prevention and treatment of autoimmune disease. Nat Rev Immunol 7:665-677.

Miller SD, McMahon EJ, Schreiner B, Bailey SL (2007b) Antigen presentation in the CNS by myeloid dendritic cells drives progression of relapsing experimental autoimmune encephalomyelitis. Ann NY Acad Sci 1103:179-191.

Newman TA, Galea I, van Rooijen N, Perry VH (2005) Blood-derived dendritic cells in an acute brain injury. J Neuroimmunol 166:167-172.

O'Connor RA, Malpass KH, Anderton SM (2007) The inflamed central nervous system drives the activation and rapid proliferation of Foxp3+ regulatory T cells. J Immunol 179:958-966.

Pashenkov M, Huang YM, Kostulas V, Haglund M, Söderström M, Link H (2001) Two subsets of dendritic cells are present in human cerebrospinal fluid. Brain 124:480-492.

Reis e Sousa C (2006) Dendritic cells in a mature age. Nat Rev Immunol 6:476-483.

Serafini B, Columba-Cabezas S, Di Rosa F, Aloisi F (2000) Intracerebral 
recruitment and maturation of dendritic cells in the onset and progression of experimental autoimmune encephalomyelitis. Am J Pathol 157:1991-2002.

Serafini B, Rosicarelli B, Magliozzi R, Stigliano E, Capello E, Mancardi GL, Aloisi F (2006) Dendritic cells in multiple sclerosis lesions: maturation stage, myelin uptake, and interaction with proliferating T cells. J Neuropathol Exp Neurol 65:124-141.

Serot JM, Béné MC, Foliguet B, Faure GC (2000) Monocyte-derived IL-10secreting dendritic cells in choroid plexus epithelium. J Neuroimmunol 105:115-119.

Sewell DL, Reinke EK, Co DO, Hogan LH, Fritz RB, Sandor M, Fabry Z (2003) Infection with Mycobacterium bovis BCG diverts traffic of myelin oligodendroglial glycoprotein autoantigen-specific $\mathrm{T}$ cells away from the central nervous system and ameliorates experimental autoimmune encephalomyelitis. Clin Diagn Lab Immunol 10:564-572.

Sewell DL, Nacewicz B, Liu F, Macvilay S, Erdei A, Lambris JD, Sandor M, Fabry Z (2004) Complement C3 and C5 play critical roles in traumatic brain cryoinjury: blocking effects on neutrophil extravasation by C5a receptor antagonist. J Neuroimmunol 155:55-63.

Shortman K, Liu YJ (2002) Mouse and human dendritic cell subtypes. Nat Rev Immunol 2:151-161.

Shortman K, Naik SH (2007) Steady-state and inflammatory dendritic-cell development. Nat Rev Immunol 7:19-30.

Steinman RM, Hawiger D, Nussenzweig MC (2003) Tolerogenic dendritic cells. Annu Rev Immunol 21:685-711.
Suter T, Biollaz G, Gatto D, Bernasconi L, Herren T, Reith W, Fontana A (2003) The brain as an immune privileged site: dendritic cells of the central nervous system inhibit $\mathrm{T}$ cell activation. Eur J Immunol 33:2998-3006.

Tang HL, Cyster JG (1999) Chemokine up-regulation and activated T cell attraction by maturing dendritic cells. Science 284:819-822.

Tang Q, Bluestone JA (2006) Plasmacytoid DCs and T(reg) cells: casual acquaintance or monogamous relationship? Nat Immunol 7:551-553.

Tang Q, Adams JY, Tooley AJ, Bi M, Fife BT, Serra P, Santamaria P, Locksley RM, Krummel MF, Bluestone JA (2006) Visualizing regulatory T cell control of autoimmune responses in nonobese diabetic mice. Nat Immunol 7:83-92.

Weir CR, Nicolson K, Bäckström BT (2002) Experimental autoimmune encephalomyelitis induction in naive mice by dendritic cells presenting a self-peptide. Immunol Cell Biol 80:14-20.

Whartenby KA, Calabresi PA, McCadden E, Nguyen B, Kardian D, Wang T, Mosse C, Pardoll DM, Small D (2005) Inhibition of FLT3 signaling targets DCs to ameliorate autoimmune disease. Proc Natl Acad Sci U S A 102:16741-16746.

Zozulya AL, Wiendl H (2008) The role of regulatory $\mathrm{T}$ cells in multiple sclerosis. Nat Clin Pract Neurol 4:384-398.

Zozulya AL, Reinke E, Baiu DC, Karman J, Sandor M, Fabry Z (2007) Dendritic cell transmigration through brain microvessel endothelium is regulated by MIP-1alpha chemokine and matrix metalloproteinases. J Immunol 178:520-529. 